Original Research

\title{
Effects of Grassland Degradation on the Distribution and Stability of Water-Stable Aggregate on the Qinghai-Tibet Plateau
}

\author{
Panpan Ma ${ }^{1,2 \#}$, Yan Qin ${ }^{3 \#}$, Hua Fu ${ }^{1}$, Liya Wang ${ }^{4}$, Zhenying Yan ${ }^{4}$, \\ Wenwen $\mathrm{Ma}^{4}$, Xilai $\mathrm{Li}^{2}$, Decao Niu${ }^{1 *}$
}

${ }^{1}$ State Key Laboratory of Grassland Agro-Ecosystems; Key Laboratory of Grassland Livestock Industry Innovation, Ministry of Agriculture and Rural Affairs; Engineering Research Center of Grassland Industry, Ministry of Education;

College of Pastoral Agriculture Science and Technology, Lanzhou University, Lanzhou, 730020, P. R. China

${ }^{2}$ College of Agriculture and Animal Husbandry, Qinghai University, Xining 810016, China

${ }^{3}$ Academy of Animal and Veterinary Sciences, Qinghai University (Qinghai Academy of Animal Science and Veterinary Medicine), Key Laboratory of Superior Forage Germplasm in the Qinghai-Tibetan Plateau, Xining 810016, China

${ }^{4}$ Qinghai Provincial Geographical Situation Monitoring Institute, Qinghai, Xining, 810008, P. R. China

\author{
Received: 6 August 2020 \\ Accepted: 10 October 2020
}

\begin{abstract}
The maintenance and stability of soil structures are critical for the stability of alpine grassland ecosystems. To elucidate how soil structures are altered by the degradation of alpine grasslands, this study investigated the various characteristics of soil aggregate particle sizes, and associated interactions with soil variables and soil stability in lightly, moderately, and severely degraded alpine steppes and meadows in Tianjun County, Qinghai Province, China. The results revealed that grassland degradation culminated in the modification of soil particle sizes from macro-aggregates $(2-0.25 \mathrm{~mm})$ to microaggregates $(0.25-0.053 \mathrm{~mm})$, to silt + clay fractions $(<0.053 \mathrm{~mm})$, and the stability of soil aggregates decreased. Moreover, the finer particle size grade might more clearly reflect soil disaggregation processes. Soil organic carbon (SOC), soil total nitrogen (STN), microbial biomass carbon (MBC), microbial biomass nitrogen (MBN) contents of both alpine steppes and alpine meadows significantly decreased with the worsening of grassland degradation. However, the microbial entropy carbon (qMBC) hardly changed, whereas the microbial entropy nitrogen (qMBN) of the severely degraded alpine steppes and alpine meadows were significantly higher than their counterparts in lightly and moderately degraded grasslands. Redundancy analysis (RDA) revealed that SOC, STN, MBC and MBN were positively correlated with the $2-1 \mathrm{~mm}$ fraction and the mean weight diameter (MWD) in both the alpine steppes
\end{abstract}

\#Authors who contributed equally to this work.

*e-mail: xiaocao0373@163.com 
and alpine meadows, but negatively correlated with the $0.25-0.1 \mathrm{~mm}$ fraction in the alpine steppes, and the $<0.053 \mathrm{~mm}$ fraction in the alpine meadows. Structural equation model (SEM) results revealed that SOC and STN were the critical factors affecting the composition and stability of soil aggregates.

Keywords: degraded grassland, soil aggregate distribution, soil aggregates stability, alpine steppe, alpine meadow

\section{Introduction}

As basic materials and functional units of soils, aggregates are porous structures of different scales that are formed through synergies between mineral particles and organic matter via biological and microphysical processes, such as soil microbial bonding, freezingthawing, and wetting-drying [1]. These entities have been classified as macro-aggregates $(>0.25 \mathrm{~mm})$, micro-aggregates $(0.25-0.053 \mathrm{~mm})$, silt + clay fractions $(<0.053 \mathrm{~mm})$ [2-3]. Soil aggregates provide sites for the storage and transformation of soil nutrients, such as carbon and nitrogen, and for the survival of microorganisms [4]. In addition, soil aggregates have the capacity of resisting external environmental changes, while maintaining the stability of soil structures [5]. Thus, the stability of soil aggregates is a fundamental property that determines soil productivity, and resistance to erosion and degradation [6], which can be expressed by a quantitative indicator, namely, mean weight diameter (MWD). Previous investigations have shown that the maintenance of soil aggregate stability is essential for increasing soil organic carbon sequestration [7], maintaining soil productivity, and reducing soil erosion and degradation [8-9]. Therefore, the distribution and stability of soil aggregates are critical indicators for the evaluation of soil quality.

China has nearly $4 \times 10^{6} \mathrm{~km}^{2}$ of grasslands, accounting for about $40 \%$ of the country's land area [10]. As a result of long-term disturbances such as irrational grazing and climate change, $90 \%$ of the available grasslands has been degraded [11]. Currently, the study of soil aggregates during grassland degradation has focused on grasslands in arid and semiarid regions [12-14]. However, there have been very few studies focusing on alpine grasslands. Moreover, the distribution and stability of soil aggregates and their responses to anthropogenic disturbances also vary with soil organic matter content, soil texture, hydrothermal conditions, and other climatic factors. For example, the soil aggregates in the typical steppe of Northwest China are dominated by $>0.5 \mathrm{~mm}$ fraction, while the $0.5-0.25 \mathrm{~mm}$ fraction aggregates are negligible. With worsening grassland degradation, the content of coarse fraction aggregates $(>0.25 \mathrm{~mm})$ decreases significantly, whereas the content of fine fraction aggregates $(<0.05 \mathrm{~mm})$ increases significantly [15]. In the desert steppe of Xinjiang, soil aggregates of a low organic matter content are composed primarily of fine particles, with the $0.1-0.25 \mathrm{~mm}$ fraction having the highest proportion, and the smallest proportion being the $>0.5 \mathrm{~mm}$ fraction, and the $>0.25 \mathrm{~mm}$ fraction in freely grazed grassland was significantly lower than that in long-term enclosed grassland [16]. Thus, soil aggregates tended to become larger following grassland degradation. On the Loess Plateau of China, soil texture is dominated by clay particles, with the highest proportion of soil aggregates comprising the $<0.25 \mathrm{~mm}$ fraction [17]. Moreover, after croplands is converted to forest and grassland, the $>2 \mathrm{~mm}$ fraction increased significantly in the topsoil [18]. These variations in particle size distribution driven by aggregation and disaggregation had a significant influence on both the macro- and micro-porosity of soil systems; thus determining the quantity and availability of soil moisture and nutrients, and the rate of gas exchanges [19]. To date, no studies have been carried out to compare the particle size changes of soil aggregates in alpine grassland that has been degraded to different severities.

Soil microorganisms are the most active biological factors in the formation of soil aggregates [20], they live in an environment that is determined by the spatial distribution of soil particles and affect the formation and stability of soil aggregates by secreting organic matter or via physical entanglement [21]. As an important indicator of soil microbial activity, soil microbial biomass carbon (MBC) accounts for only $1 \%-5 \%$ of the SOC [22], whereas microbial biomass nitrogen (MBN) accounts for about $0.5 \%-15.3 \%$ of the soil total nitrogen (STN) [23]. The soil microbial quotient is the ratio of soil microbial carbon and nitrogen to SOC and STN, which reflects the proportion of active organic matter, and effectively reveals the dynamic changes in soil organic matter, and the stability of soil structure [24]. Previous studies revealed that the effects of soil structure on soil microorganisms are primarily initiated through the modified distribution of soil aggregates [25]. Therefore, quantifying the changes of soil microorganisms is important for predicting the effects of future changes in the intensity of management on the stability of soil aggregates. However, investigations into the relationships between soil microbial biomass and soil aggregates in degraded grasslands on the QinghaiTibet Plateau have not been undertaken yet.

As an important animal husbandry base in China, the Qinghai-Tibet Plateau is one of the most sensitive regions on Earth to global climate change [26]. Currently, the grassland on the Qinghai-Tibet Plateau has endured different degrees of degradation due to anthropogenic interference, with the appearance of the "black soil land" in some areas [27-28]. Grassland 
Table 1. The basic characteristics of sample areas.

\begin{tabular}{|c|c|c|c|c|c|c|c|}
\hline $\begin{array}{c}\text { Grassland } \\
\text { type }\end{array}$ & $\begin{array}{c}\text { Degradation } \\
\text { gradient }\end{array}$ & Dominant species & $\begin{array}{c}\text { Coverage } \\
(\%)\end{array}$ & $\begin{array}{c}\text { Species } \\
\text { number }\end{array}$ & $\begin{array}{c}\text { Grass height } \\
(\mathrm{cm})\end{array}$ & $\begin{array}{c}\text { Aboveground } \\
\text { biomass } \\
\left(\mathrm{g} / \mathrm{m}^{2}\right)\end{array}$ & $\begin{array}{c}\text { Belowground } \\
\text { biomass } \\
\left(\mathrm{g} / \mathrm{m}^{2}\right)\end{array}$ \\
\hline \multirow{2}{*}{$\begin{array}{c}\text { Alpine } \\
\text { steppe }\end{array}$} & $\mathrm{LD}$ & $\begin{array}{c}\text { Stipa purpurea }+ \\
\text { Elymus nutans }\end{array}$ & $78 \%-80 \%$ & $12.50 \pm 0.51 \mathrm{a}$ & $17.63 \pm 0.45 \mathrm{a}$ & $446.08 \pm 29.38 \mathrm{a}$ & $3656.57 \pm 314.73 \mathrm{a}$ \\
\cline { 2 - 8 } & $\mathrm{MD}$ & $\begin{array}{c}\text { Stipa purpurea }+ \text { Poa } \\
\text { pratensis }\end{array}$ & $51 \%-54 \%$ & $8.50 \pm 0.28 \mathrm{~b}$ & $9.47 \pm 0.36 \mathrm{~b}$ & $319.76 \pm 27.35 \mathrm{~b}$ & $1541.83 \pm 51.89 \mathrm{~b}$ \\
\hline \multirow{2}{*}{$\begin{array}{c}\text { Alpine } \\
\text { meadow }\end{array}$} & $\mathrm{SD}$ & $\begin{array}{c}\text { Stipa purpurea }+ \\
\text { P.bifurca }\end{array}$ & $38 \%-40 \%$ & $8.01 \pm 0.50 \mathrm{~b}$ & $6.55 \pm 0.72 \mathrm{c}$ & $156.76 \pm 5.01 \mathrm{c}$ & $1396.95 \pm 290.84 \mathrm{~b}$ \\
\cline { 2 - 8 } & $\mathrm{MD}$ & $\begin{array}{c}\text { Kobresia graminifolia } \\
+ \text { Kobresia pygmaea }\end{array}$ & $96 \%-98 \%$ & $13.25 \pm 0.62 \mathrm{a}$ & $18.43 \pm 0.67 \mathrm{a}$ & $1176.23 \pm 125.97 \mathrm{a}$ & $13927.59 \pm 3020.62 \mathrm{a}$ \\
\cline { 2 - 7 } & $\mathrm{KD}$ Carex moorcroftii & $93 \%-95 \%$ & $12.00 \pm 0.91 \mathrm{a}$ & $15.06 \pm 0.73 \mathrm{~b}$ & $970.24 \pm 102.07 \mathrm{a}$ & $8402.72 \pm 1637.63 \mathrm{~b}$ \\
\hline
\end{tabular}

Different letters in each column indicate significant differences $(P<0.05$; Duncan's test). LD - lightly degraded; MD - moderately degraded; SD- severely degraded.

degradation has led to the breakdown of soil aggregate structures, which enhances the interactions between soil microorganisms and soil organic matter, and accelerates organic matter decomposition, which can result in a serious loss of soil carbon and nitrogen [29-30]. Therefore, it is important to study soil aggregates in alpine steppe and alpine meadow that are widely distributed on the Qinghai-Tibet Plateau. This study aims to reveal (i) the characteristics of soil particle size distribution and stability of alpine grassland during grassland degradation; and (ii) the relationships between soil variables and the distribution and stability of soil aggregates during alpine grassland degradation.

\section{Materials and Methods}

\section{Study Area}

The study area $\left(96^{\circ} 49^{\prime}-99^{\circ} 41^{\prime} \mathrm{E}, 36^{\circ} 53^{\prime}-48^{\circ} 39^{\prime} \mathrm{N}\right)$ is located in Tianjun County of Qinghai Province on the northeastern Qinghai-Tibet Plateau. This mountainous area has an altitude ranging from 2,850 to $5,827 \mathrm{~m}$. It has a continental and plateau climate with an average annual temperature of $-1.5^{\circ} \mathrm{C}$ and an average annual precipitation of $360 \mathrm{~mm}$. There is almost no frost-free period throughout the year. The grassland area of Tianjun County is $1.57 \times 10^{4} \mathrm{~km}^{2}$, of which alpine meadow accounts for $45.67 \%$, alpine steppe for $13.69 \%$, degraded black soil beach and windy sand land for $4.17 \%$. Both frigid alpine grassland/meadow soil in alpine steppe is shallow, and of a light coarse quality [31]. The grassland had been degraded to various levels from light, to moderate and severe. Based on the particle size distribution of soil aggregates proposed by Six [32], soil aggregates are further classified as macro-aggregates $(2-0.25 \mathrm{~mm})$, micro- aggregates $(0.25-0.053 \mathrm{~mm})$, and silt and clay fraction $(<0.053 \mathrm{~mm})$.

\section{Experimental Design}

According to the grading standard of natural grassland degradation in Qinghai Province [33], the degradation of grassland is divided into three severity grades: light, moderate, and severe. Typical alpine steppe and alpine meadow of different degrees of degradation inside the Buha River Basin within the study area were selected to study soil and vegetation properties via in situ sampling. Detailed characteristics of the sampling areas is shown in Table 1.

\section{Sample Collection}

In mid-July 2017, a flat terrain with a relatively consistent soil texture inside the study area was selected for each level of degradation severity along three $50 \mathrm{~m}$ transects perpendicular to a water channel. Along each transect, three $1 \mathrm{~m} \times 1 \mathrm{~m}$ quadrants were established at a distance of 15,25 and $45 \mathrm{~m}$ from the water channel, to survey vegetation properties, and to collect plant and soil samples. During the vegetation survey, the species and total coverage were recorded, and the aboveground portions of the plants were cut off in parallel to the ground to determine their aboveground biomass. Subsequently, within each sampling plot four soil samples from the $0-10 \mathrm{~cm}$ depth were extracted with a $5 \mathrm{~cm}$ diameter earth drill, and combined to form one soil sample. The mixed soil samples were transported to the laboratory where all any animal and plant residues and small stones were removed. The resultant soil samples were used to analyze the characteristics of the soil aggregates, and soil physical and chemical properties. 


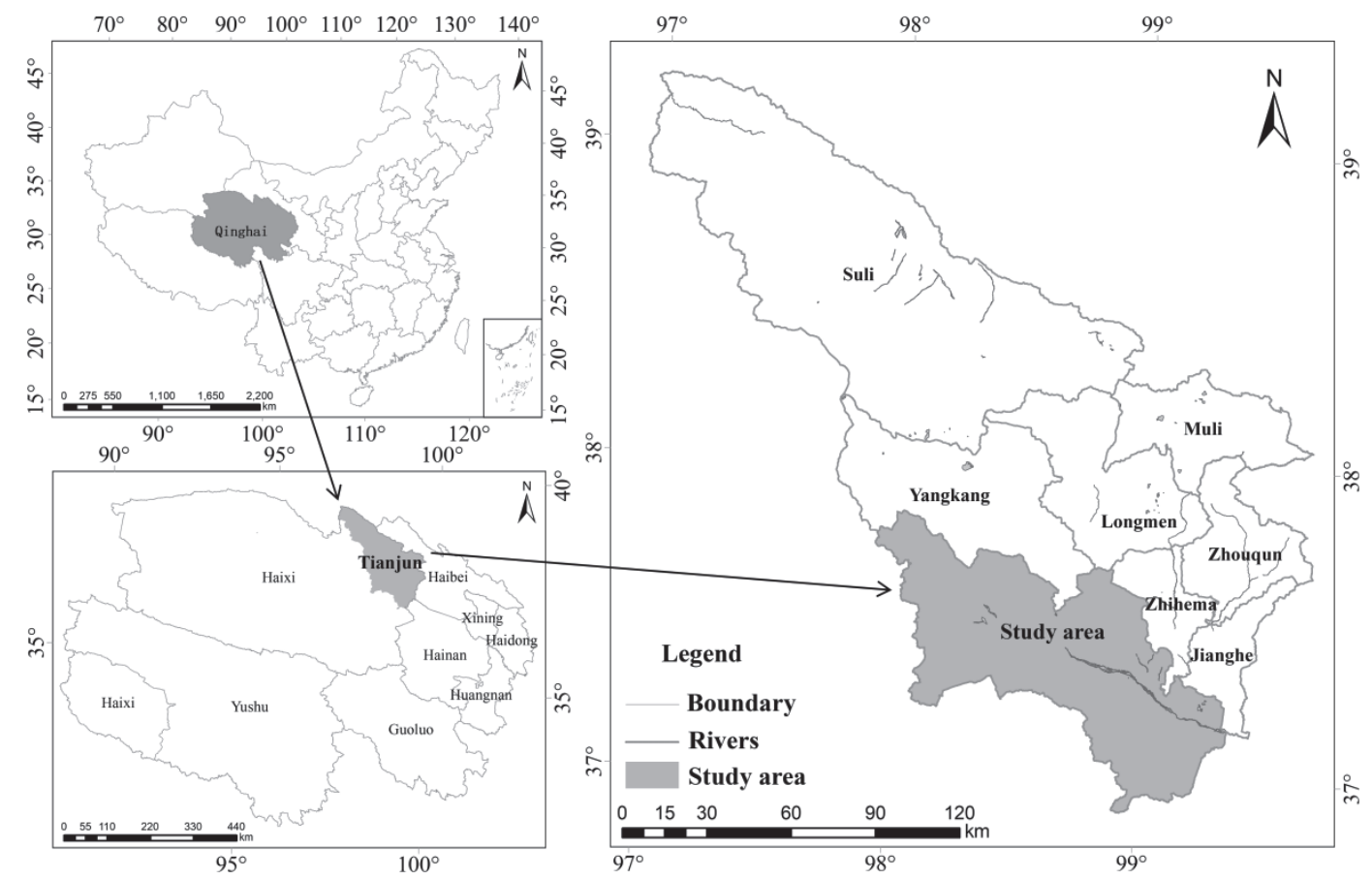

Fig. 1. Location of the study area in Tianjun County, Qinghai Province, China.

\section{Soil Fractionation}

The standard procedure described by Cambardella and Elliott was used to separate water-stable aggregates [34]. About $100 \mathrm{~g}$ of $<2 \mathrm{~mm}$ air-dried soils from the processed samples were sieved to five grades using a mesh size of $1.00,0.50,0.25,0.1$ and $0.053 \mathrm{~mm}$, respectively. The sieved soils were pre-soaked in distilled water for $5 \mathrm{~min}$, during which the water-soil mixture was vertically oscillated 30 times using a $3.8 \mathrm{~cm}$ amplitude at a rate of one oscillation per second. The soil particles on the topmost sieve were always below the surface of the water during each oscillation. Following wet-sieving, the water-stable soil materials remained on sieves of a unique mesh size (the five mesh sizes are 1.00, 0.50, 0.25, 0.1 and $0.053 \mathrm{~mm}$ ). The remaining soil materials sieved with a unique mesh size were separately transferred to a beaker, dried in an oven at $60^{\circ} \mathrm{C}$ for $48 \mathrm{~h}$, weighed and stored for analysis. The percentage ratio of aggregates in each mesh size represented the water-stable aggregates for the six classes of particle size: $2-1 \mathrm{~mm}, 1-0.5 \mathrm{~mm}, 0.5-0.25 \mathrm{~mm}$, $0.25-0.1 \mathrm{~mm}, 0.1-0.053 \mathrm{~mm}$, and $<0.053 \mathrm{~mm}$.

\section{Analysis of Soil Chemical Properties}

The SOC and STN of the processed soil samples were determined using dichromate digestion and the micro-Kjeldahl method, respectively [35]. MBC and MBN were determined using the chloroform fumigation extraction method [36-37]. Briefly, two $25 \mathrm{~g}$ soil subsamples were extracted with $50 \mathrm{ml}$ of $0.5 \mathrm{M} \mathrm{K}_{2} \mathrm{SO}_{4}$ for $30 \mathrm{~min}$ on a shaker, and another two subsamples were fumigated with chloroform for $24 \mathrm{~h}$ at $25^{\circ} \mathrm{C}$ in a vacuum desiccator, followed by the identical extraction procedure to that of the unfumigated samples. The estimated soil microbial $\mathrm{C}$ and $\mathrm{N}$ was essentially the difference in extractable $\mathrm{C}$ and $\mathrm{N}$ between the fumigated and unfumigated soils based on the extractability correction factors: $K_{C}=0.45$ for $\mathrm{C}$ and $K_{N}=0.54$ for $\mathrm{N}$ [38].

\section{Calculation and Statistical Analysis}

The percentage of the stable aggregates remaining on each sieve representing the water stable aggregates was calculated using the formula from Beare [39]:

$$
W_{i}=\frac{W_{0}}{W_{T}} \times 100 \%
$$

...where $W_{o}$ is the mass of $i$ th size resistant aggregates fraction $(\mathrm{g}), W_{T}$ is the total mass of wet-sieved soil (g), and $W_{i}$ is the concentration of the $i$ th size fraction (\%).

The mean weight diameter (MWD) was employed to estimate the stability of the aggregates. It was calculated using the formula from Dexter [40]:

$$
\mathrm{MWD}=\sum_{i=1}^{\mathrm{n}} \bar{X}_{l} \times W_{i}
$$

...where $X_{i}$ is the mean diameter of the $i$ th size fraction (mm); and $W_{i}$ is the concentration of the $i$ th size fraction $(\%)$.

The microbial entropy was calculated using the formula from Bormann [41]: 


$$
\begin{array}{r}
\mathrm{qMBC}=\mathrm{C}_{\min } / \mathrm{C}_{\text {org }} \\
\mathrm{qMBN}=\mathrm{N}_{\min } / \mathrm{N}_{\text {tot }}
\end{array}
$$

...where $\mathrm{C}_{\min }$ is microbial biomass carbon; and $\mathrm{C}_{\text {org }}$ is the soil organic carbon; $\mathrm{N}_{\min }$ is microbial biomass nitrogen, and $\mathrm{N}_{\text {tot }}$ is soil total nitrogen.

One-way ANOVA analysis followed by the Tukey method was employed to evaluate the influence of the degradation gradient on the bulk soil properties and the distribution and stability of soil aggregates. The significance level was set at $P<0.05$. Redundancy analysis (RDA) was employed to analyze the relationship between soil variables and the distribution and stability of soil aggregates during the degradation of alpine grasslands. Additionally, Pearson's analysis was performed to determine the correlation between the distribution and stability of soil aggregates and the environmental variables.

Further, we performed structural equation model (SEM) to identify how grassland degradation indirectly impacted the distribution of water-stable aggregates, from the mechanisms of soil biotic and abiotic nutrients changes. Prior to performing SEM, principal component analysis (PCA) was used to reduce the number of variables to simplify the analyses and facilitate interpretations, including grassland degradation (coverage, aboveground biomass, belowground biomass), soil organic matter (SOC, STN), microbial entropy (qMBC, qMBN), soil microbial biomass (MBC, MBN) and aggregate distribution $\left(\mathrm{R}_{2-1}, \mathrm{R}_{1-0.5}, \mathrm{R}_{0.5-0.25}, \mathrm{R}_{0.25-0.1}, \mathrm{R}_{0.1-0.053}, \mathrm{R}_{<0.053}\right)$. All indices were utilized as raw data in the PCA. Subsequently, the first principal component (PC1) was used for SEM analysis to represent the grassland degradation (PC1 explained $87.50 \%$ and $87.43 \%$ of the variation in the alpine steppe and alpine meadow, respectively; Fig. S1), soil organic matter ( $\mathrm{PC1}$ explained $98.47 \%$ and $98.25 \%$ of the variation in alpine steppe and alpine meadow, respectively; Fig. S2), soil microbial biomass (PC1 explained $81.67 \%$ and $83.46 \%$ of the variation in alpine steppe and alpine meadow, respectively; Fig. S3), microbial entropy ( $\mathrm{PCl}$ explained $67.22 \%$ and $58.57 \%$ of the variation in alpine steppe and alpine meadow, respectively, Fig. S4), and aggregate distribution (PC1 explained $64.65 \%$ and $71.49 \%$ of the variation in alpine steppe and alpine meadow, respectively; Fig. S5).

All statistical analyses were performed in SPSS 22.0, and the results were plotted using Sigmaplot 12.5 and Canoco 5.0.

\section{Results}

\section{Aggregate Size Distribution and Their Stability}

Two-way analysis of variance revealed that the soil aggregate content and distribution in the alpine steppe and alpine meadow varied with grassland degradation and aggregate size, both individually and jointly (Fig. 2). In the lightly degraded grassland, the soil aggregates of the alpine steppe and alpine meadow were dominated by the $2-1 \mathrm{~mm}$ fraction, accounting for $39.40 \%$ and $52.53 \%$ of the total soil aggregates, respectively. In the moderately degraded grassland, the proportion of soil aggregates in the $0.5-0.25 \mathrm{~mm}$ fraction was the highest in the alpine steppe. While in the alpine meadow, the dominant soil aggregate was still the 2-1 $\mathrm{mm}$ fraction. This was significantly lower $(P<0.05)$ than that in the lightly degraded grassland. The proportion of soil aggregates in the $0.25-0.1 \mathrm{~mm}$ fraction was significantly higher than that in the lightly and severely degraded grasslands $(P<0.05)$. In the severely degraded grassland, The soil aggregates most common in the alpine steppe and alpine meadow have a particle size of the $0.25-0.1 \mathrm{~mm}$ and $0.5-0.25 \mathrm{~mm}$ fractions, respectively, which were significantly higher than those in the lightly and moderately degraded grasslands $(P<0.05)$ (Fig. 2a, Fig. 2c).

On the whole, grassland degradation promoted the destruction of soil aggregates. The specific manifestation is that the soil aggregates of the two types of degraded grasslands were primarily $2-0.25 \mathrm{~mm}$, where only the $2-0.25 \mathrm{~mm}$ fraction significantly decreased, and $0.25-0.053 \mathrm{~mm}$ fraction significantly increased in the severely degraded alpine steppe $(P<0.05)$. The $2-0.25 \mathrm{~mm}, 0.25-0.053 \mathrm{~mm}$ and $<0.053 \mathrm{~mm}$ fractions in the alpine meadow did not vary significantly with degradation severity $(P>0.05)$. However, a detailed classification of soil particle size revealed that with intensified grassland degradation, soil aggregates of the alpine steppe and alpine meadow showed an obvious transition from macro-aggregates to micro-aggregates and to silt + clay fractions.

The MWD of soil aggregates in the alpine grassland varied with the level of degradation (Fig. 3). With the intensification of grassland degradation, the MWD decreased in both the alpine steppe and alpine meadow. There were significant differences between the three degradation gradients in the alpine meadow. However, the MWD was not significantly different between the moderately and severely degraded grasslands in alpine steppe $(P<0.05)$.

\section{Nutrients Content in Bulk Soils}

The SOC and STN contents were significantly different between the alpine steppe and alpine meadow (Fig. 4). The SOC and STN contents were $19.21-42.40 \mathrm{~g} / \mathrm{kg}$ and $1.55-3.79 \mathrm{~g} / \mathrm{kg}$, respectively, in alpine steppe, $47.25-144.88 \mathrm{~g} / \mathrm{kg}$ and $3.56-10.51 \mathrm{~g} / \mathrm{kg}$, respectively, in alpine meadow. With the intensification of grassland degradation, the SOC and STN contents of both grasslands showed a significant decreasing trend $(P<0.05)$. The SOC/STN ratio of the alpine steppe and alpine meadow was $9.92-12.31$ and 11.86-13.78, respectively. The SOC/STN ratio had a variable response to different 

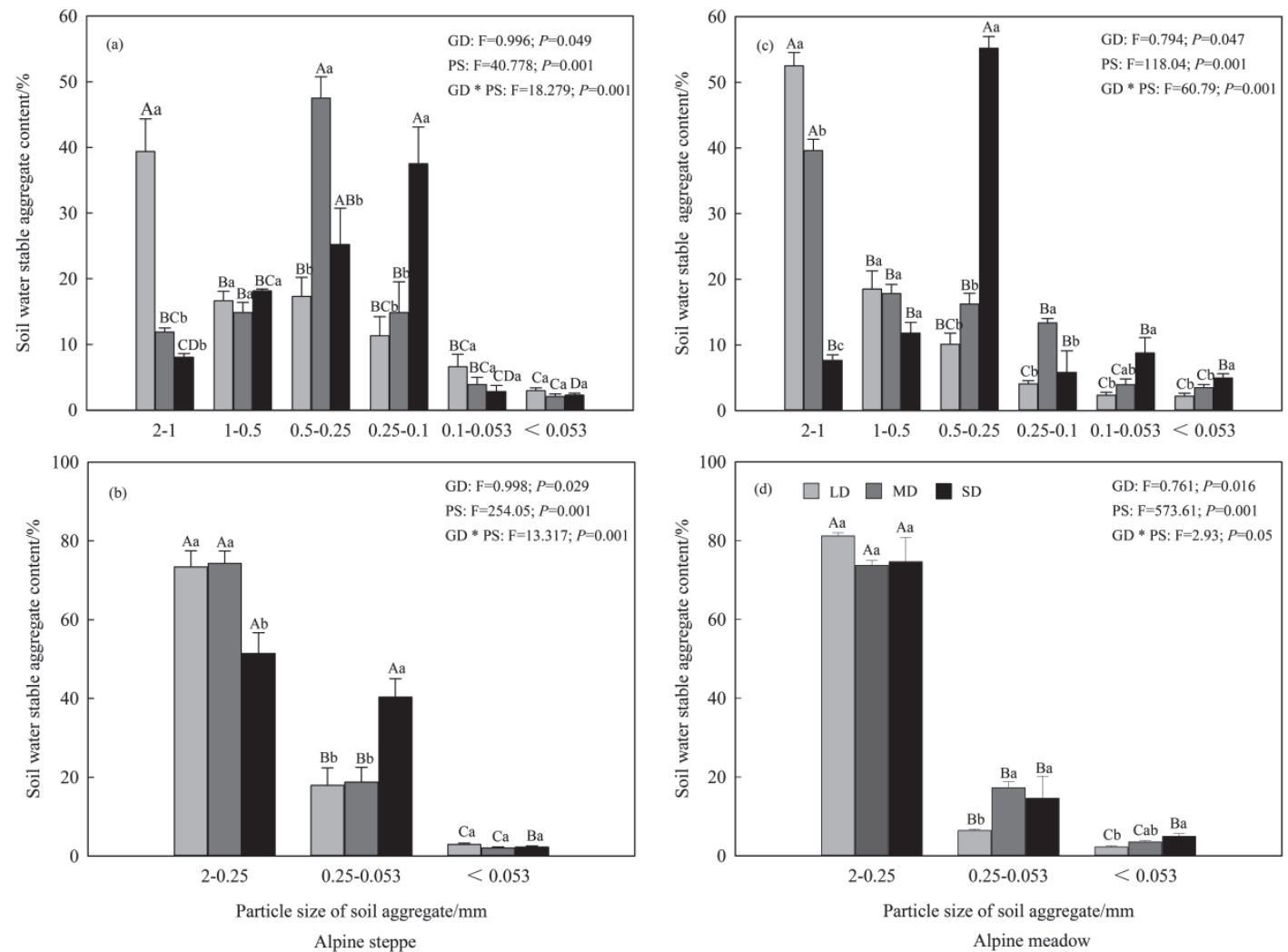

Fig. 2. Fraction of soil water-stable aggregates in alpine steppe (left plots) and alpine meadow (right plots) with different degradation severities. Different lowercase letters refer to a significant difference at the 0.05 level between different grassland degradation gradients of the same particle size. Different capital letters refer to a significant difference between different particle sizes under the same degradation gradient at the 0.05 level. GD - Grassland degradation; PS - Particle size.

degrees of degradation. The variation of SOC/STN ratio of the alpine steppe with degradation severity followed the trend of severely degraded > lightly degraded $>$ moderately degraded, whereas the trend for the SOC/STN ratio of the alpine meadow were lightly degraded $\approx$ severely degraded $>$ moderately degraThe MBC content of the alpine steppe and alpine meadow was $292.59-750.20 \mathrm{mg} / \mathrm{kg}$ and $66.95-131.27 \mathrm{mg} / \mathrm{kg}$, respectively. The corresponding figures for the MBN content was $487.51-558.21 \mathrm{mg} / \mathrm{kg}$ and $143.43-218.65 \mathrm{mg} / \mathrm{kg}$, respectively. In both the alpine steppe and alpine meadow, the MBC of the lightly degraded grassland was all significantly higher than that of the moderately degraded and severely degraded grasslands $(P<0.05)$. However, there was no significant difference between the moderately and severely degraded grasslands. The MBN exhibited a definite trend in the alpine steppe across different degradation gradients: lightly

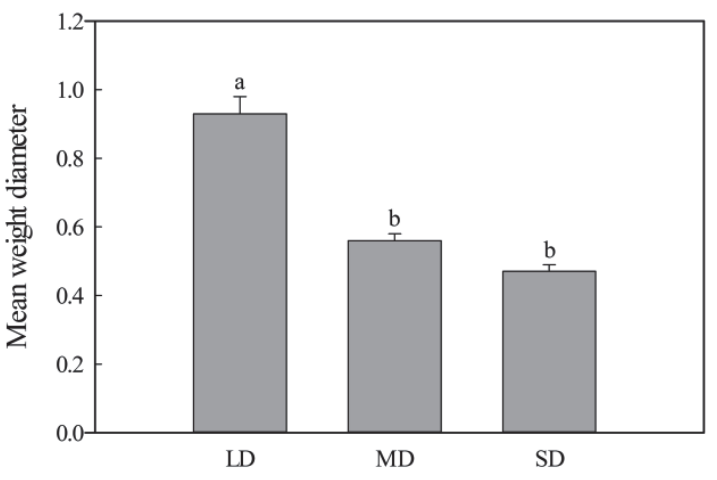

Alpine steppe

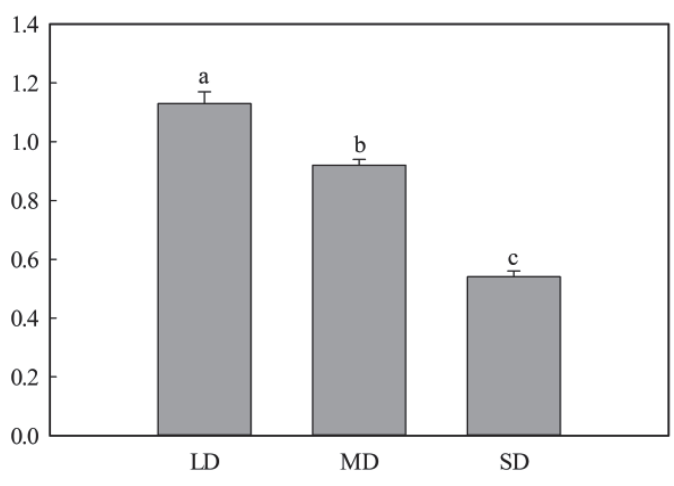

Alpine meadow

Fig. 3. Mean weight diameter of soil aggregates with different degradation levels. Different letters refer to a significant difference at the 0.05 level. MWD - mean weight diameter; LD - lightly degraded; MD - moderately degraded; SD - severely degraded. 

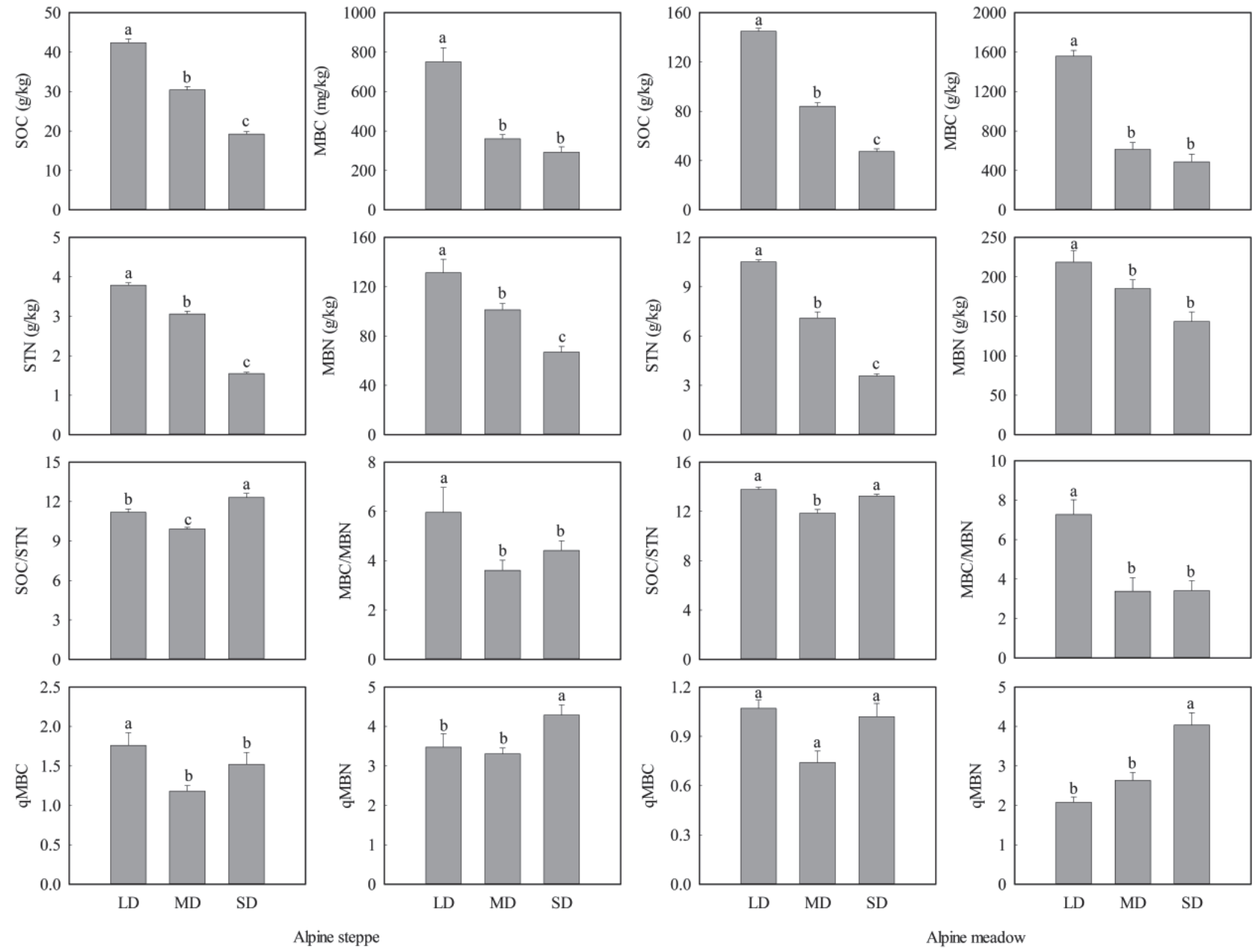

Fig. 4. Soil nutrients content of alpine steppe (left plots) and alpine meadow (right plots) with different degradation levels. Different letters indicate a significant difference at the 0.05 level. SOC - Soil organic carbon; STN - Soil total nitrogen; MBC - Microbial biomass carbon; MBN - microbial biomass nitrogen; qMBC - Microbial entropy carbon; qMBN - Microbial entropy nitrogen; LD - lightly degraded; MD - moderately degraded; SD - severely degraded.

degraded $>$ moderately degraded $>$ severely degraded $(P<0.05)$, while the response of MBN to grassland degradation in the alpine meadow was consistent with that of $\mathrm{MBC}$. The $\mathrm{MBC} / \mathrm{MBN}$ ratio of the two types of grasslands was 3.61-5.96 and 3.38-7.27, respectively. In both the alpine steppe and alpine meadow, MBC/MBN ratio in the lightly degraded grassland was significantly higher than in the moderately and severely degraded grasslands $(P<0.05)$. The $\mathrm{qMBC}$ of the alpine steppe and the alpine meadow was $1.18 \%-1.76 \%$ and $0.74 \%$ $1.07 \%$, respectively, and the qMBN was $3.30 \%-4.28 \%$ and $2.08 \%-4.03 \%$, respectively. The qMBC of the lightly degraded alpine steppe was significantly higher than its moderately and severely degraded counterparts $(P<0.05)$, and the qMBC of the alpine meadow did not vary significantly with degradation gradient $(P>0.05)$; However, the qMBN in severely degraded both alpine steppe and alpine meadow was significantly higher than their lightly and moderately degraded counterparts $(P<0.05)$.

\section{Relationship between Soil Aggregates and Soil Properties}

Redundancy analysis (RDA) was employed to identify those soil variables that influenced the distribution of soil aggregate particle sizes and stability during grassland degradation. The cumulative interpretation rate of the first two axes was $81.3 \%$ and $85.9 \%$ for the alpine steppe and alpine meadow, respectively (Fig. 5, Table S1). The results indicated that each soil variable is able to explain $1.4 \%-47.0 \%$ of the changes in the distribution and stability of soil aggregates in the alpine steppe $(0.8 \%-53.7 \%$ in alpine meadow) (Table 2). The observed variations in soil aggregates particle size and stability were significantly correlated with certain specific soil variables (Table S2). In the alpine steppe, SOC, STN, MBC, and MBN were positively correlated with the MWD and 2-1 mm fraction $(P<0.05$, Table S2), while they were negatively correlated with the $0.25-0.1 \mathrm{~mm}$ fraction $(P<0.05$, Table S2). In the alpine meadow, SOC, STN, 

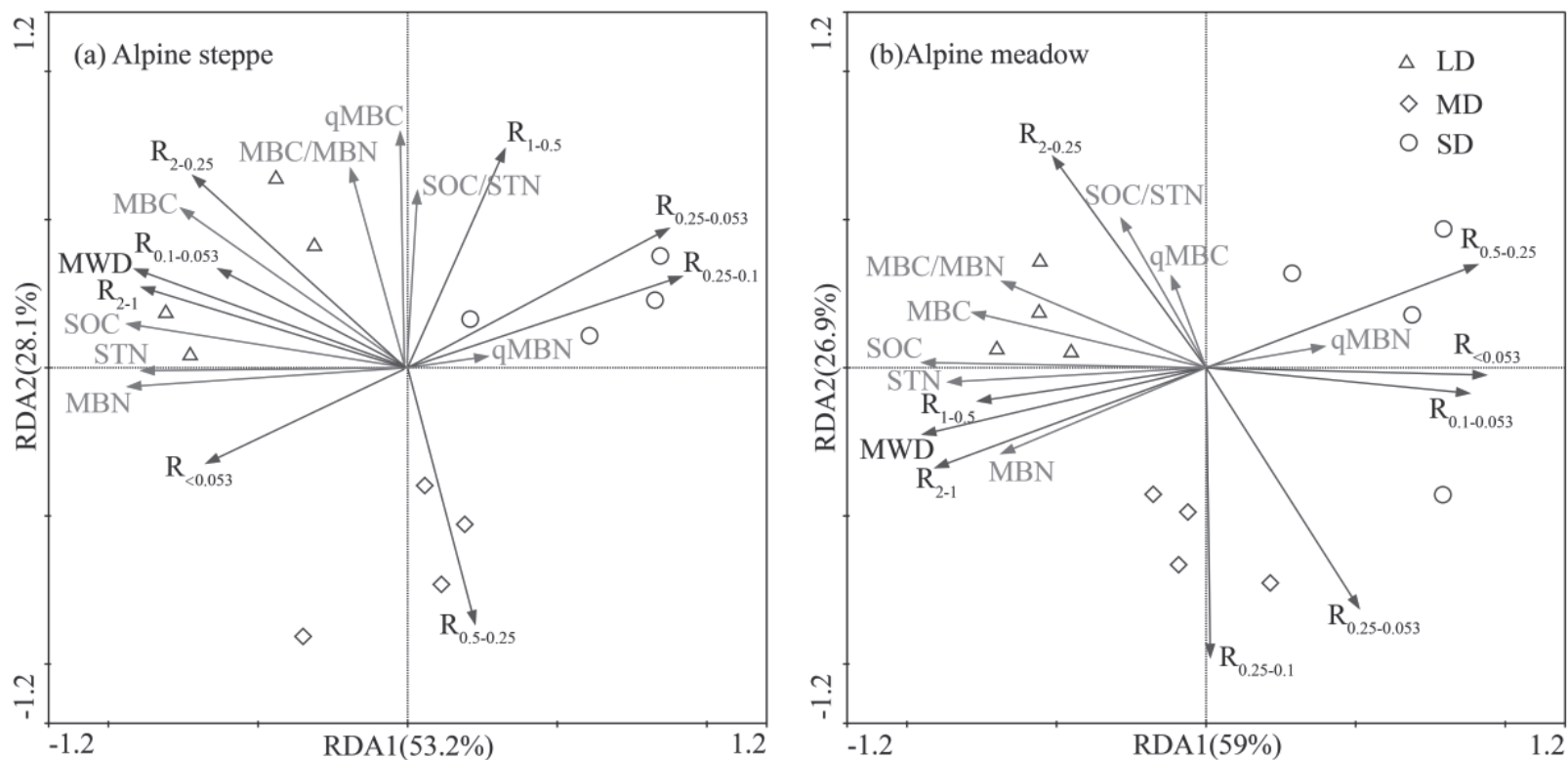

Fig. 5. Relationships between soil aggregates and soil variables in a) alpine grassland and $b$ ) with different degrees of degradation. $R_{2-1}$ represents the proportion of soil aggregates with 2-1 mm fraction; $\mathrm{R}_{1-0.5}$ represents the proportion of soil aggregates with particle size of $1-0.5 \mathrm{~mm} ; \mathrm{R}_{0.5-0.25}$ represents the $0.5-0.25 \mathrm{~mm}$ fraction; $\mathrm{R}_{0.25-0.1}$ represents the $0.25-0.1 \mathrm{~mm}$ fraction; $\mathrm{R}_{0.1-0.053}$ represents the $0.1-0.053 \mathrm{~mm}$ fraction; $\mathrm{R}_{<0.053}$ represents the $<0.053 \mathrm{~mm}$ fraction.

$\mathrm{MBC}$, and MBN were positively correlated with the MWD and the 2-1 $\mathrm{mm}$ fraction $(P<0.05)$, which was significantly and negatively correlated with the $<0.053$ $\mathrm{mm}$ fraction $(P<0.05$, Table S2).

Overall, SOC, STN, SOC/STN, MBC, MBN, $\mathrm{MBC} / \mathrm{MTN}$ and $\mathrm{qMBC}$ in the alpine steppe and alpine meadow was positively correlated with the $2-0.25 \mathrm{~mm}$ fraction and MWD, but negatively correlated with the 0.25-0.053 mm fraction. Moreover, SOC, STN, MBC and MBN in the alpine steppe and alpine meadow decreased gradually, whereas the stability of soil structure decreased with the intensified degradation of grasslands. The proportion of soil aggregates in the $2-0.25 \mathrm{~mm}$ fraction decreased, but increased in the $0.25-0.053 \mathrm{~mm}$ fraction, which further verified that the soil aggregates of the two types of grassland gradually changed from the macro-aggregates to microaggregates, and further to silt + clay fractions.

Furthermore, the SEM showed a good fit between grassland degradation, soil organic matter, microbial entropy, soil microbial biomass, and aggregate distribution (alpine steppe: $\chi^{2}=0.415, \mathrm{~d} f=1$, $P=0.0 .520$, RMSEA $=0.000$; alpine meadow: $\chi^{2}=0.098, \mathrm{~d} f=1, P=0.754$, RMSEA $=0.000$, respectively) (Fig. 6). Our results revealed that the degradation of alpine steppe and alpine meadow had

Table 2. Variations of soil aggregates distribution and stability explained by soil variables during grassland degradation.

\begin{tabular}{|c|c|c|c|c|c|c|}
\hline & \multicolumn{3}{|c|}{ Alpine steppe } & \multicolumn{3}{|c|}{ Alpine meadow } \\
\hline & Explains (\%) & $F$ & $P$ & Explains (\%) & $F$ & $P$ \\
\hline $\mathrm{SOC}$ & 47.0 & 8.9 & 0.002 & 53.7 & 11.6 & 0.002 \\
\hline STN & 26.3 & 8.8 & 0.002 & 16.2 & 4.9 & 0.022 \\
\hline MBN & 6.0 & 3.0 & 0.005 & 10.5 & 4.3 & 0.016 \\
\hline MBC & 5.5 & 2.0 & 0.016 & 2.7 & 1.1 & 0.034 \\
\hline qMBC & 2.6 & 1.2 & 0.338 & 0.8 & 0.3 & 0.754 \\
\hline qMBN & 3.3 & 1.3 & 0.258 & 1.0 & 0.4 & 0.746 \\
\hline SOC/STN & 1.7 & 0.8 & 0.482 & 1.0 & 0.4 & 0.788 \\
\hline $\mathrm{MBC} / \mathrm{MBN}$ & 1.4 & 0.6 & 0.632 & 5.6 & 2.5 & 0.126 \\
\hline
\end{tabular}

SOC - Soil organic carbon; STN - Soil total nitrogen; MBC - Microbial biomass carbon; MBN - microbial biomass nitrogen; qMBC

- Microbial entropy carbon; qMBN - Microbial entropy nitrogen. 

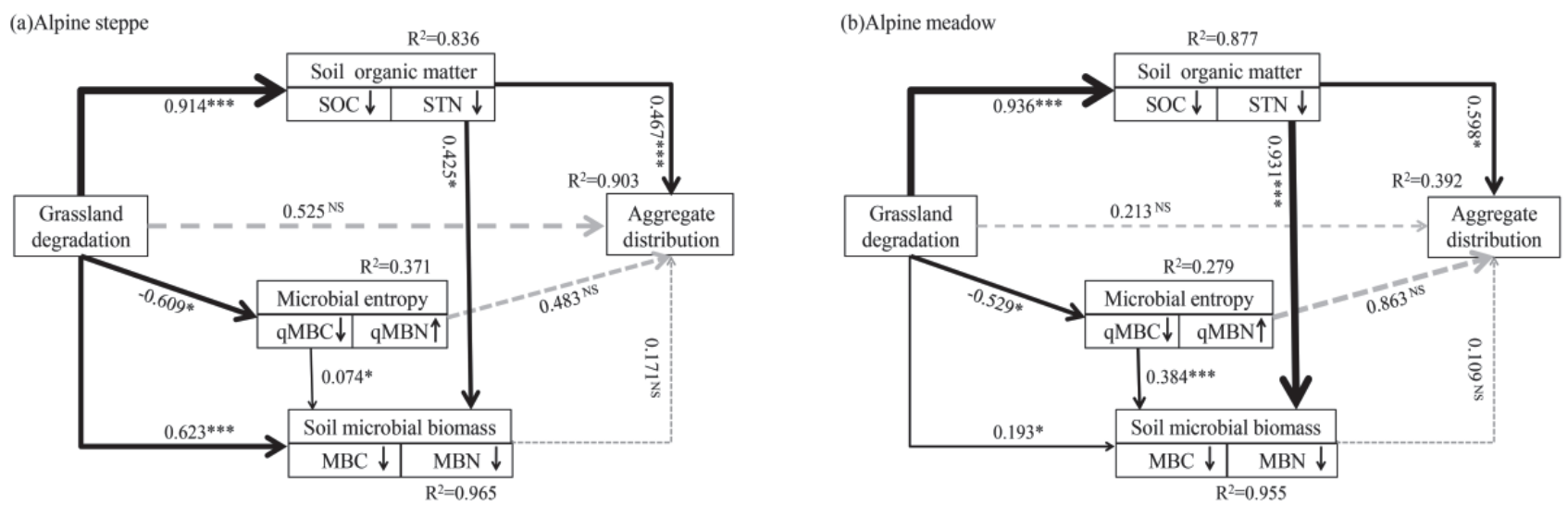

Fig. 6. Structural Equation Model (SEM) based on the effects of grassland degradation, soil organic matter, microbial entropy and soil microbial biomass on soil aggregate distribution (Alpine steppe: $\chi^{2}=1.175, \mathrm{~d} f=1, P=0.186, \mathrm{RMSEA}=0.000$; Alpine meadow: $\chi^{2}=$ $1.348, \mathrm{~d} f=1, P=0.524$, RMSEA $=0.000)$. Solid arrows represent significant relationships; dashed arrows indicate insignificant path coefficients $(p>0.05)$. Values associated with arrows indicate standardized path coefficients $\left({ }^{*} p<0.05 ; * * p<0.01 ; * * * p<0.001\right)$. Arrow width corresponds to the standardized path coefficient. $\mathrm{R}^{2}$ associated with response variables represent the proportion of explained variation by other variables. SOC - Soil organic carbon; STN - Soil total nitrogen; MBC - Microbial biomass carbon; MBN - Microbial biomass nitrogen; qMBC - Microbial entropy carbon; qMBN - Microbial entropy nitrogen.

positive effects on the decrease of soil organic matter and microbial biomass $(P<0.001)$, but negative effects on the decrease of soil microbial entropy $(P<0.05)$. Soil organic matter significantly and positively affected microbial biomass and soil aggregate distribution $(P<0.05)$, while soil microbial biomass and microbial entropy were not significantly correlated with the distribution of soil aggregates $(P>0.05)$.

\section{Discussion}

Based on the particle size classification of soil aggregates by Six [32], this study further refined the sizes of soil aggregates and compared them with the findings of previous studies, which reported the $<0.25 \mathrm{~mm}$ fraction of soil aggregates in the degraded grassland as being the dominant particle size [42-44]. However, the results of this study revealed that the 2-0.25 $\mathrm{mm}$ fraction was dominant in the alpine steppe and alpine meadow. A further detailed classification of the soil particle size showed that in lightly degraded grassland, the soil aggregates of the alpine steppe and alpine meadow were dominated by the $2-1 \mathrm{~mm}$ fraction; In moderately degraded grassland, the $0.5-0.25 \mathrm{~mm}$ fraction of soil aggregates has the largest proportion in the alpine steppe, while the size of soil aggregate that dominated the alpine meadow was still the 2-1 $\mathrm{mm}$ fraction; In severely degraded grassland, the soil aggregates in the alpine steppe and alpine meadow possessed the largest proportion of $0.25-0.1 \mathrm{~mm}$ and $0.5-0.25 \mathrm{~mm}$ particle size, respectively.

Soil aggregates comprise the basic materials and functional units of soil, and their particle size distribution is closely related to its physical and chemical properties and soil structure stability, and are sensitive to various disturbances $[5,12,45]$. In this study, with the intensification of grassland degradation, the soil aggregates of both alpine steppe and alpine meadow showed a trend of transitioning from macroaggregates to micro-aggregates and further to the silt + clay fractions, which were consistent with the findings reported in the literature [46, 47, 13]. These results further illustrated that a detailed classification of soil particle sizes can more clearly reflect the process involved in the structural changes of soils during grassland degradation.

Soil organic matter is the core substance that maintains soil structure and influences the soil microenvironment [48, 7]. Grassland degradation can affect the accumulation and decomposition of soil organic matter [49]. In this study, the SOC and STN content in the alpine steppe and alpine meadow showed a trend of lightly degraded $>$ moderately degraded $>$ severely degraded $(P<0.05)$, which was primarily due to the intensification of grassland degradation. A lower vegetation cover and reduced aboveground biomass resulted in a reduced organic matter input to the soil as a major source of nutrients, and decreased soil carbon sequestration [50]. Further, soil aggregates are a critical component of soil structure and have an important physical and biological mechanism for protecting soil organic carbon and nitrogen [42]. Grassland degradation leads to the breakdown of soil aggregate structure, which increases the contact area of microorganisms and organic carbon within the aggregate; thus, accelerating the decomposition of soil organic carbon and nitrogen and decreasing their contents [29-30]. Previous studies found that the SOC and STN content and distribution of soil aggregates were related to aggregates size and microbial activity [51-52]. This study also found that with the intensification of grassland degradation, the 
soil aggregates of both types of grassland exhibited an obvious transition from macro-aggregates to microaggregates and further to silt + clay fractions. In addition, the stability of soil aggregates gradually decreased, which was consistent with the changes in the SOC and STN content.

Soil microorganisms are essential for decomposition of soil organic matter, which affects the turnover of soil organic carbon and nitrogen [53, 25]. While soil microbial biomass is primarily determined by the soil organic matter content [48]. As grassland degradation intensifies, the energy and nutrients on which soil microbes depend for survival decrease. Further, the soil environment that is suitable for microbial survival deteriorates severely, which results in decreased microbial biomass and metabolic activity $[54,55]$. In this study, the contents of MBC and MBN in the two types of grassland soils in the lightly degraded grassland were significantly higher than in the moderately and severely degraded grassland $(P<0.05)$, while no significant difference existed between moderately and severely degraded. The changes of $\mathrm{qMBC}$ in the alpine steppe at different degrees of degradation were consistent with those of $\mathrm{MBC}$; however, qMBC content was not significantly different in the alpine meadow with different degrees of degradation $(P>0.05)$. The qMBN of the severely degraded alpine steppe and alpine meadow were significantly higher than their counterparts in lightly and moderately degraded grasslands. It may be explained by the fact that the rupturing of soil aggregates under severe degradation enlarged the surface contact area between microorganisms and soil organic carbon. Subsequently, this increased the concentration of nutrients that could be directly utilized by microorganisms, thus alleviating the sharp decrease in microbial biomass. Additionally, in contrast to the moderately degraded and severely degraded grassland, the lightly degraded grassland had a topsoil rich in dense roots that provided favorable conditions for the growth and reproduction of microorganisms, which significantly improved soil microbial biomass and qMBN.

The SOC/STN ratio can reflect the decomposition of soil organic matter and the potential mineralization and retention of soil carbon-nitrogen by microorganisms [56]. In this study, the SOC/STN ratio of moderately degraded alpine steppe and alpine meadow grasslands were significantly lower than that of the lightly and severely degraded grasslands, indicating that the potential nitrogen mineralization rate increased in the moderately degraded grassland, which may have been caused by the destruction of soil structures under moderate degradation, where the assimilation of soil organic carbon by microorganisms was greater [5758]. In addition, the higher the $\mathrm{MBC} / \mathrm{MBN}$ ratio, the greater the proportion of fungi in the soil microbial community to some extent $[55,52]$. In this study, MBC/ MBN ratio in both types of grasslands responded differently to the degree of degradation, in which
$\mathrm{MBC} / \mathrm{MBN}$ ratio increased significantly under lightly degraded, but did not change under moderately and severely degraded $(P<0.05)$. There was no significant difference between moderately and severely degraded. These results indicated that the proportion of fungi in the soil microbial communities decreased, whereas the proportion of bacteria increased following grassland degradation. In conclusion, grassland degradation affected the soil organic matter transformation process and the structure of the soil microbial community. However, the kinetics behind the structural adjustment of soil microbial communities induced by soil decomposition remains unknown.

The MWD is a comprehensive indicator that reflects the stability of soil aggregates [59-60]. The larger the MWD, the more stable the soil aggregates [61]. Grassland degradation disrupts the physical barriers of soil aggregates between microorganisms, enzymes, organic carbon and nitrogen, which enhances the microorganism decomposition, as well as the turnover rate of organic carbon and nitrogen, thus, leading to a less stable soil structure, with a decreased proportion of macro-aggregates, and an increased proportion of micro-aggregates and silt and clay fraction $[53,25]$. The RDA results revealed that soil variables can effectively explain the modifications of soil particle size and stability during grassland degradation. Certain soil variables had a significant correlation with particle size and stability. For instance, SOC, STN, MBC and MBN were positively correlated with the $2-1 \mathrm{~mm}$ fraction and MWD in both the alpine steppe and alpine meadow, and negatively correlated with $0.25-0.1 \mathrm{~mm}$ fraction in the alpine steppe and $<0.053 \mathrm{~mm}$ fraction in the alpine meadow. The results of SEM further revealed that the degradation of alpine steppe and alpine meadow resulted in the decrease of soil organic matter and soil microbial biomass, but increased soil microbial entropy. Moreover, soil organic matter positively affected the transformation of soil macro-aggregates to micro-aggregates and to slit + clay fractions. However, soil microbial biomass and microbial entropy were not significantly correlated with soil aggregate stability. Although soil microorganisms were involved in various ecological processes, such as the decomposition of organic matter, the formation of humus, and transformation cycle of soil nutrients [48], it had a relatively negligible impact on the formation of soil aggregates. While soil organic matter was an important cementer during the formation of agglomerates, its content was critical to the formation of soil aggregates [7].

\section{Conclusions}

Grassland degradation affects the particle size distribution and stability of soil aggregates in alpine steppe and alpine meadow. With the intensification of grassland degradation, soil aggregates exhibited a significant transition from macro-aggregates 
(2-0.25 $\mathrm{mm})$ to micro-aggregates $(0.25-0.053 \mathrm{~mm})$, and further to the silt and clay fraction $(<0.053 \mathrm{~mm})$ in both the steppe and meadow. The stability of soil aggregates gradually decreased with degradation severity. Moreover, the detailed classification of soil particle sizes into six grades were able to more clearly reveal the processes of the soil structural changes during grassland degradation. Meanwhile, the SOC, STN, MBC and MBN contents in the alpine steppe and alpine meadow decreased significantly, while qMBC had relatively moderate changes. The qMBN of the severely degraded grassland in both the alpine steppe and alpine meadow was significantly higher than that of the lightly and moderately degraded grasslands. The SOC, STN, MBC and $\mathrm{MBN}$ were positively correlated with the $2-1 \mathrm{~mm}$ fraction and MWD in both the alpine steppe and alpine meadow, while they were negatively correlated with the $0.25-0.1 \mathrm{~mm}$ fraction in the alpine steppe and the $<0.053 \mathrm{~mm}$ fraction in the alpine meadow. Soil organic matter was essential to the formation and stability of soil aggregates.

\section{Acknowledgements}

This study was supported by the science and technology plan of Qinghai province (2018-ZJ-941Q), the National Natural Science Foundation of China (41671106, 31572458), Key Laboratory of Superior Forage Germplasm in the Qinghai-Tibetan Plateau, Qinghai (2020-ZJ-Y03), the Changjiang Scholars and Innovative Research Team in University (IRT_17R50), and the 111 project (B12002). We thank Ze Ren for his kind review and suggestions for this manuscript. We thank Zhaomin Wang and Ying Wang for the help with sampling. We also thank Frank Boehm for improving the language.

\section{Conflict of Interest}

The authors declare no conflict of interest.

\section{References}

1. COSENTINO D., CHENU C., BISSONNAIS Y.L. Aggregate stability and microbial community dynamics under drying-wetting cycles in a silt loam soil. Soil Biology and Biochemistry, 38 (8), 2053, 2006.

2. TISDALL J.M., OADES J.M. Organic matter and waterstable aggregates in soils. European Journal of Soil Science, 2 (33), 141, 2010.

3. MURUGAN R., PARAMA V. R. R., MADAN B., MUTHURAJU R., LUDWIG B. Short-Term Effect of Nitrogen Intensification on Aggregate Size Distribution, Microbial Biomass and Enzyme Activities in a Semi-Arid Soil Under Different Crop Types. Pedosphere, 29 (4), 483, 2019.

4. BRONICK C.J., LAL R. Soil structure and management: a review. Geoderma, 124 (1), 3, 2005.
5. LIUSUI Y.H., ZHU X.P., LI D.P., YAN C.X., SUN T., JIA H.T., ZHAO X.N. Soil aggregate and intra-aggregate carbon fractions associated with vegetation succession in an alpine wetland of Northwest China. Catena, 181, 2019.

6. WALIA M.K., DICK W.A. Selected soil physical properties and aggregate-associated carbon and nitrogen as influenced by gypsum, crop residue, and glucose. Geoderma, 320, 67, 2018.

7. TRIVEDI P., ROCHESTER I.J., TRIVEDI C., VAN NOSTRAND J.D., ZHOU J., KARUNARATNE S., ANDERSON I.C., SINGH B.K. Soil aggregate size mediates the impacts of cropping regimes on soil carbon and microbial communities. Soil Biology and Biochemistry, 91, 169, 2015.

8. WANG Y.X., RAN L.S., FANG N.F., SHI Z.H. Aggregate stability and associated organic carbon and nitrogen as affected by soil erosion and vegetation rehabilitation on the Loess Plateau. Catena, 167, 257, 2018.

9. BRYAN R.B. Soil erodibility and processes of water erosion on hill slope. Geomorphology, 32 (3), 385, 2000.

10. PENG F., XUE X., YOU Q.G., HUANG C.H., DONG S.Y., LIAO J., DUAN H.C., ATSUSHI T.K., WANG T. Changes of soil properties regulate the soil organic carbon loss with grassland degradation on the Qinghai-Tibet Plateau. Ecological Indicators, 93, 572, 2018.

11. WANG S.Q., LI T.X., ZHENG Z.C. Effect of tea plantation age on the distribution of soil organic carbon and nutrient within micro-aggregates in the hilly region of western Sichuan, China. Ecological Engineering, 90, 113, 2016.

12. AN S.S., DARBOUX F., CHENG M. Revegetation as an efficient means of increasing soil aggregate stability on the Loess Plateau (China). Geoderma, 209 (1), 75, 2013.

13. WANG Y.X., FANG N.F., ZHANG F.B., WANG L., WU G.L., YANG M.Y. Effects of erosion on the microaggregate organic carbon dynamics in a small catchment of the Loess Plateau, China. Soil and Tillage Research, 174, 205, 2017.

14. ZENG Q.C., DARBOUX F, MAN C., ZHU Z.L., AN, S.S. Soil aggregate stability under different rain conditions for three vegetation types on the Loess Plateau (China). Catena, 167, 276, 2018.

15. ZHAO Y.G., ZHAO S.W., HUA J., ZHANG, Y. Soil structural properties of enclosed steppe in the semiarid area. Acta Agrestia Sinica, 17, 106, 2009.

16. LIU W.T., WANG T.L., ZHANG S., DING L.J., LÜ, S.J., WEI, Z.J. Effects of grazing on edificators and soil aggregate characteristics in Stipa breviflora desert steppe. Ecology and Environmental Sciences, 26 (6), 978, 2017.

17. CHEN W.Y., XU X.X., HUA R., DING K., SHAHMIR A.K., DU F. Effects of forestlands and grasslands on soil aggregates under different vegetation restoration ages in loess hilly region. Acta Scientiae Circumstantiae, 37 (4), 1486, 2017.

18. WANG Y.X., RAN L.S., FANG N.F., SHI Z.H. Aggregate stability and associated organic carbon and nitrogen as affected by soil erosion and vegetation rehabilitation on the Loess Plateau. Catena, 167, 257, 2018.

19. SPACCINI R., PICCOLO A. Effects of field managements for soil organic matter stabilization on water-stable aggregate distribution and aggregate stability in three agricultural soils. Journal of Geochemical Exploration, 129, 45, 2013.

20. WANG S.Q., LI T.X., ZHENG Z.C., CHEN Y.H. Soil aggregate-associated bacterial metabolic activity and community structure in different aged tea plantations. Science of the Total Environment, 654, 1023, 2019. 
21. WANG H., WANG S., WANG R., ZHANG Y., WANG X., LI J. Direct and indirect linkages between soil aggregates and soil bacterial communities under tillage methods. Geoderma, 354, 2019.

22. JIANG X.J., SHI X.L., WRIGHT A.L. Seasonal variability of microbial biomass associated with aggregates in a ricebased ecosystem. European Journal of Soil Biology, 56 (56), 84, 2013.

23. ANDERSON, J.P.E., DOMSCH, K.H. Quantities of plant nutrients in the microbial biomass of selected soils. Soil Science, 130 (4), 211, 1980.

24. ANDERSON T.H., DOMSCH K.H. Ratios of microbial biomass carbon to total organic carbon in arable soils. Soil Biology and Biochemistry, 21 (4), 471, 1989.

25. TRIVEDI P., ROCHESTER I.J., TRIVEDI C., NOSTRAND J.D.V., ZHOU J.Z., KARUNARATNE S., ANDERSON L.C., SINGH B.K. Soil aggregate size mediates the impacts of cropping regimes on soil carbon and microbial communities. Soil Biology and Biochemistry, 91, 1LI W., WANG J.L., ZHANG X.J., SHI S.L., CAO W.X. Effect of degradation and rebuilding of artificial grasslands on soil respiration and carbon and nitrogen pools on an alpine meadow of the QinghaiTibetan Plateau. Ecological Engineering, 111, 134, 2018

26. DONG S.K., SHERMAN R.E. Enhancing the resilience of coupled human and natural systems of alpine rangelands on the Qinghai-Tibetan Plateau. The Rangeland Journal, 37 (1), 2015

27. GANG C.C., ZHOU W., CHEN Y.Z., WANG Z.Q., SUN Z.G., LI J.L., QI J.G., ODEH I. Quantitative assessment of the contributions of climate change and human activities on global grassland degradation. Environmental Earth sciences, 72 (11), 4273, 2014.

28. ZHANG Z.C., HOU G., LIU M., WEI T.X., SUN J. Degradation induces changes in the soil C:N:P stoichiometry of alpine steppe on the Tibetan Plateau. Journal of Mountain Science, 16 (10), 2348, 2019.

29. GAO L.L., WANG B.S., LI S.P., WU H.J., WU X.P., LIANG G.P., GONG D.Z., ZHANG X.M., CAI D.X., DEGRÉ A. Soil wet aggregate distribution and pore size distribution under different tillage systems after 16 years in the Loess Plateau of China. Catena, 173, 38, 2019.

30. LI M.Z. Research on the re-vegetation mode of the deteriorated grassland "bare land" in Tianjun. Qinghai Prataculture, 27 (3), 21, 2018.

31. SIX J., CONANT R.T., PAUL E.A., PAUSTIAN K. Stabilization mechanisms of soil organic matter: Implications for C-saturation of soils. Plant and Soil, 241 (2), 155, 2002.

32. XUE X., GUO J., HAN B.S., SUN Q.W., LIU L.C. The effect of climate warming and permafrost thaw on desertification in the Qinghai-Tibetan Plateau. Geomorphology, 108 (3), 182, 2009.

33. CAMBARDELLA C.A., ELLIOTT E.T. Methods for physical separation and characterization of soil organic matter fractions. Geoderma, 56(4), 449, 1993.

34. CHEN F.L., ZHENG H., ZHANG K., QUYANG Z.Y., WU Y.F., SHI Q., LI H.L. Non-linear impacts of Eucalyptus plantation stand age on soil microbial metabolic diversity. Journal of Soils and Sediments, 13 (5), 887, 2013

35. VANCE E.D., BROOKES P.C., JENKINSON D.S. An extraction method for measuring soil microbial biomass C. Soil Biology and Biochemistry, 19 (6), 703, 1987.

36. KHAN K.S., JOERGENSEN R.G. Stoichiometry of the soil microbial biomass in response to amendments with varying $\mathrm{C} / \mathrm{N} / \mathrm{P} / \mathrm{S}$ ratios. Biology and Fertility of Soils, $\mathbf{5 5}$ (3), 265, 2019

37. Heuck C., Weig A., Spohn M. Soil microbial biomass $\mathrm{C}: \mathrm{N}: \mathrm{P}$ stoichiometry and microbial use of organic phosphorus. Soil Biology and Biochemistry, 85, 119, 2015.

38. BEARE M.H., HENDRIX P.F., COLEMAN D.C. Water-stable aggregates and organic matter fractions in conventional and no-tillage soils. Soil Science Society of America Journal, 58 (3), 777, 1994.

39. DEXTER A.R. Advances in characterization of soil structure. Soil and Tillage Research, 11 (3), 199, 1988.

40. BORMANN E.J., GROSSE H.H., MENZ J. Entropy balances of microbial product formation. Biotechnology Advances, 8 (1), 277, 1990.

41. SIX J., ELLIOTT E.T., PAUSTIAN K. Soil macroaggregate turnover and micro-aggregate formation: a mechanism for $\mathrm{C}$ sequestration under no-tillage agriculture. Soil Biology and Biochemistry, 32 (14), 2099, 2000.

42. DOU S., LI K., GUAN S. A review on organic matter in soil aggregates. Acta Pedologica Sinica, 48 (2), 412, 2011.

43. CHEN S., SUN T. Research of soil aggregates stability in different degradation stages of Songnen grassland. Pratacultural Science, 34 (2), 217, 2017.

44. MORAES M.T.D., DEBIASI H., CARLESSO R., FRANCHINI J.C., SILVA V.R.D., LUZ F.B.D. Soil physical quality on tillage and cropping systems after two decades in the subtropical region of Brazil. Soil and Tillage Research, 155, 351, 2016.

45. Li C.L., Cao Z.Y., Chang J.J., ZHANG Y., ZHU G.L., ZONG N., HE Y.T., ZHANG J.J., HE N.P. Elevational gradient affect functional fractions of soil organic carbon and aggregates stability in a Tibetan alpine meadow. Catena, 156, 139, 2017.

46. AYOUBI S., KARCHEGANI P.M., MOSADDEGHI M.R., HONARJOO N. Soil aggregation and organic carbon as affected by topography and land use change in western Iran. Soil and Tillage Research, 121, 18, 2012

47. ZHAO F.Z., REN C.J., HAN X.H., YANG G.H., WANG J., DOUGHTY R. Changes of soil microbial and enzyme activities are linked to soil $\mathrm{C}, \mathrm{N}$ and $\mathrm{P}$ stoichiometry in afforested ecosystems. Forest Ecology and Management, 427, 289, 2018

48. YUAN Z.Q., JIANG X.J., LIU G.J., JIN H.J., CHEN J., WU Q.B. Responses of soil organic carbon and nutrient stocks to human-induced grassland degradation in a Tibetan alpine meadow. Catena, 178, 40, 2019.

49. BARGALI K., MANRAL V., PADALIA K., BARGALI S.S., UPADHYAY V.P. Effect of vegetation type and season on microbial biomass carbon in Central Himalayan forest soils, India. Catena, 171, 125, 2018.

50. ZHU G.Y., SHANGGUAN, Z.P., DENG L. Soil aggregate stability and aggregate-associated carbon and nitrogen in natural restoration grassland and Chinese red pine plantation on the Loess Plateau. Catena. 149, 253, 2017.

51. YANG C., LIU N., ZHANG Y.J. Soil aggregates regulate the impact of soil bacterial and fungal communities on soil respiration. Geoderma, 337, 444, 2019.

52. TISDALL J.M., OADES J.M. Organic matter and waterstable aggregates in soils. Journal of Soil Science, 33 (2), 141, 2010.

53. DING X.L., CHEN S.Y., ZHANG B., LIANG C., HE, H.B., HORWATH W.R. Warming increases microbial residue contribution to soil organic carbon in an alpine meadow. Soil Biology and Biochemistry, 135, 13, 2019. 
54. KIM J.M., ROH A.S., CHOI S.C., KIM E.J., CHOI M.T., AHN B.K., KANG S.S. Soil pH and electrical conductivity are key edaphic factors shaping bacterial communities of greenhouse soils in Korea. Journal of Microbiology, 54 (12), 838, 2016.

55. SPOHN M., PÖTSCH E.M., EICHORST S.A., WOEBKEN D., WANEK W., RICHTER A. Soil microbial carbon use efficiency and biomass turnover in a long-term fertilization experiment in a temperate grassland. Soil Biology and Biochemistry, 97, 168, 2016.

56. FENG D.F., BAO W.K. Review of the temporal and spatial patterns of soil C:N:P stoichiometry and its driving factors. Chinese Journal of Applied and Environmental Biology, 23 (2), 400, 2017.

57. XU X.R., WANG J.K. A Review on Different Stabilized Mechanisms of Soil Aggregates and Organic Carbon. Chinese Journal of Soil Science, 48, 1523, 2017.
58. BISSONNAIS Y.L. Aggregate stability and assessment of soil crustability and erodibility: I. Theory and methodology. European Journal of Soil science, 48 (1), 39, 2010.

59. ZHAO F.Z., FAN X.D., REN C.J., ZHANG L., HAN X.H., YANG G.H., WANG J., DOUGHTY R. Changes of the organic carbon content and stability of soil aggregates affected by soil bacterial community after afforestation. Catena, 171, 622, 2018.

60. WANG Z.Q., ZHANG Y.Z., YANG Y., ZHOU W., GANG C.C., ZHANG Y., LI J.L., AN R., WANG K., ODEH I., QI J.G. Quantitative assess the driving forces on the grassland degradation in the Qinghai-Tibet Plateau, in China. Ecological Informatics, 33, 32, 2016. 


\section{Supplementary Materials}

Table S1.1. Canonical coefficients of soil variables and aggregate distribution of the RDA in alpine steppe.

\begin{tabular}{|c|c|c|c|c|c|}
\hline Axes & 1 & 2 & 3 & 4 & Total variance \\
\hline Eigenvalues & 0.532 & 0.281 & 0.087 & 0.011 & 1.000 \\
\hline Aggregate distribution- soil variables correlation & 0.985 & 0.989 & 0.954 & 0.668 & \\
\hline Cumulative percentage variance of aggregate distribution & 53.2 & 81.4 & 90.1 & 91.2 & \\
\hline $\begin{array}{c}\text { Cumulative percentage variance of aggregate distribution - } \\
\text { soil variables }\end{array}$ & 58.0 & 88.7 & 98.2 & 99.4 & \\
\hline Sum of all eigenvalues & \multicolumn{5}{|c|}{1.000} \\
\hline Sum of all canonical eigenvalues & \multicolumn{5}{|c|}{0.917} \\
\hline
\end{tabular}

Table S1.2. Canonical coefficients of soil variables and aggregate distribution of the RDA in Alpine meadow.

\begin{tabular}{|c|c|c|c|c|c|}
\hline Axes & 1 & 2 & 3 & 4 & Total variance \\
\hline Eigenvalues & 0.590 & 0.269 & 0.034 & 0.020 & 1.000 \\
\hline $\begin{array}{c}\text { Aggregate distribution- soil variables correlation } \\
\text { Cumulative percentage variance of aggregate distribution }\end{array}$ & 0.962 & 0.984 & 0.858 & 0.855 & \\
\hline $\begin{array}{c}\text { Cumulative percentage variance of aggregate distribution - } \\
\text { soil variables }\end{array}$ & 64.3 & 93.5 & 97.2 & 99.5 & \\
\hline Sum of all eigenvalues & & & \\
\hline Sum of all canonical eigenvalues & & \multicolumn{3}{|c|}{0.91 .000} & \\
\hline
\end{tabular}

Table S2.1. Correlation analysis of soil variables and soil aggregate size distribution and stability in alpine steppe.

\begin{tabular}{|c|c|c|c|c|c|c|c|c|c|}
\hline & $\mathrm{MWD}$ & $\mathrm{R}_{2-1}$ & $\mathrm{R}_{1-0.5}$ & $\mathrm{R}_{0.5-0.25}$ & $\mathrm{R}_{0.25-0.1}$ & $\mathrm{R}_{0.1-0.053}$ & $\mathrm{R}_{<0.053}$ & $\mathrm{R}_{2-0.25}$ & $\mathrm{R}_{0.25-0.053}$ \\
\hline SOC & $0.914 * * *$ & $0.888^{* * *}$ & -0.199 & -0.298 & $-0.831^{* *}$ & $0.629 *$ & 0.533 & $0.710^{* *}$ & $-0.775^{* *}$ \\
\hline $\mathrm{STN}$ & $0.801 * *$ & $0.769 * *$ & -0.258 & -0.118 & $-0.846^{* *}$ & $0.588^{*}$ & 0.411 & $0.771^{* *}$ & $-0.810^{* *}$ \\
\hline SOC/STN & 0.333 & 0.348 & $-0.654 *$ & 0.496 & $-0.930^{* * *}$ & 0.271 & 0.276 & 0.553 & $-0.949 * * *$ \\
\hline MBC & $0.868 * *$ & $0.845^{* *}$ & 0.179 & $-0.584 *$ & $-0.568 *$ & $0.713 * *$ & $0.712 * *$ & 0.374 & -0.450 \\
\hline MBN & $0.868 * * *$ & $0.852^{* * *}$ & -0.393 & -0.153 & $-0.860 * * *$ & 0.504 & 0.385 & $0.808^{* *}$ & $-0.845 * *$ \\
\hline MBC/ & 0.496 & 0.481 & 0.526 & $-0.656 *$ & -0.103 & 0.552 & $0.615 *$ & -0.107 & 0.037 \\
\hline MBN & $0.563 *$ & $0.557 *$ & $0.597 *$ & $-0.787 *$ & 0.057 & $0.582 *$ & $0.697 *$ & -0.159 & 0.096 \\
\hline qMBC & -0.206 & -0.186 & 0.011 & -0.040 & 0.297 & -0.235 & -0.034 & -0.278 & 0.294 \\
\hline
\end{tabular}

Significance level are as follows: $* P<0.01 ; * * P<0.01 ; * * * P<0.001$; SOC - Soil organic carbon; STN - Soil total nitrogen; MBC - Microbial biomass carbon; MBN - microbial biomass nitrogen; qMBC - Microbial entropy carbon; qMBN - Microbial entropy nitrogen. 
Table S2.2. Correlation analysis of soil variables and soil aggregate size distribution and stability in alpine meadow.

\begin{tabular}{|c|c|c|c|c|c|c|c|c|c|}
\hline & MWD & $\mathrm{R}_{2-1}$ & $\mathrm{R}_{1-0.5}$ & $\mathrm{R}_{0.5-0.25}$ & $\mathrm{R}_{0.25-0.1}$ & $\mathrm{R}_{0.1-0.053}$ & $\mathrm{R}_{<0.053}$ & $\mathrm{R}_{2-0.25}$ & $\mathrm{R}_{0.25-0.053}$ \\
\hline SOC & $0.934 * * *$ & $0.900 * * *$ & $0.675^{*}$ & $-0.837 * *$ & -0.166 & $-0.716 * *$ & $-0.894 * * *$ & 0.416 & -0.493 \\
\hline STN & $0.968^{* * *}$ & $0.943 * * *$ & $0.721 * *$ & $-0.904 * * *$ & -0.027 & $-0.750 * *$ & $-0.898 * * *$ & 0.365 & -0.404 \\
\hline SOC/STN & 0.066 & 0.045 & -0.052 & 0.160 & $-0.817 * *$ & -0.037 & -0.216 & 0.444 & $-0.655^{*}$ \\
\hline $\mathrm{MBC}$ & $0.778 * *$ & $0.718^{* *}$ & 0.495 & $-0.627 *$ & -0.335 & -0.533 & $-0.750 * *$ & 0.421 & -0.544 \\
\hline $\mathrm{MBN}$ & $0.775^{* *}$ & $0.814^{* *}$ & 0.357 & $-0.789 * *$ & 0.122 & -0.465 & $-0.616^{*}$ & 0.023 & -0.125 \\
\hline $\begin{array}{l}\mathrm{MBC} / \\
\mathrm{MBN}\end{array}$ & $0.642 *$ & 0.550 & 0.503 & -0.463 & -0.386 & -0.479 & $-0.655^{*}$ & 0.485 & -0.572 \\
\hline qMBC & 0.435 & 0.418 & 0.463 & -0.561 & -0.595 & $-0.652^{*}$ & $0.639^{*}$ & $0.908 * * *$ & $-0.909 * * *$ \\
\hline qMBN & $-0.900 * * *$ & $-0.872 * *$ & $-0.819 * *$ & $0.851 * *$ & -0.046 & $0.835^{* *}$ & $0.900 * *$ & -0.465 & 0.387 \\
\hline
\end{tabular}

Significance level are as follows: $* P<0.01$; $* * P<0.01$; *** $P<0.001$; SOC - Soil organic carbon; STN - Soil total nitrogen; MBC - Microbial biomass carbon; MBN - microbial biomass nitrogen; qMBC - Microbial entropy carbon; qMBN - Microbial entropy nitrogen.

Table S3. Summary of results and fittings of the final structural equation model analysis.

\begin{tabular}{|c|c|c|c|c|c|c|}
\hline \multicolumn{7}{|l|}{ I Alpine steppe. } \\
\hline \multicolumn{7}{|c|}{ Notes for Model (Default model) } \\
\hline \multirow{3}{*}{ Computation of degrees of freedom } & \multicolumn{6}{|c|}{ Number of distinct sample moments $=15$} \\
\hline & \multicolumn{6}{|c|}{ Number of distinct parameters to be estimated $=14$} \\
\hline & \multicolumn{6}{|c|}{ Degrees of freedom $(15-14)=1$} \\
\hline \multicolumn{7}{|c|}{ Result (Default model) } \\
\hline \multicolumn{7}{|c|}{ Minimum was achieved } \\
\hline \multicolumn{7}{|c|}{ Chi-square $=0.415$} \\
\hline \multicolumn{7}{|c|}{ Probability level $=0.520$} \\
\hline \multicolumn{7}{|c|}{ Estimates (Group number 1 - Default model): Maximum Likelihood Estimates } \\
\hline & & Estimate & S.E. & C.R. & $\mathrm{P}$ & Label \\
\hline \multicolumn{2}{|c|}{ Soil organic matter $\longleftarrow$ Grassland degradation } & 0.914 & 0.122 & 7.483 & $* * *$ & par_1 \\
\hline \multicolumn{2}{|c|}{ Microbial entropy $\leftarrow$ Grassland degradation } & -0.609 & 0.239 & 2.547 & 0.011 & par_3 \\
\hline \multicolumn{2}{|c|}{ Soil microbial biomass $\leftarrow$ Grassland degradation } & 0.623 & 0.140 & 4.453 & $* * *$ & par_2 \\
\hline \multicolumn{2}{|c|}{ Soil microbial biomass $\leftarrow$ Microbial entropy } & 0.074 & 0.072 & 1.029 & 0.033 & par_ 8 \\
\hline \multicolumn{2}{|c|}{ Soil microbial biomass $\leftarrow$ Soil organic matter } & 0.426 & 0.141 & 3.016 & 0.003 & par_7 \\
\hline \multicolumn{2}{|c|}{ Aggregate distribution $\leftarrow$ Soil organic matter } & 0.467 & 0.335 & 4.377 & $* * *$ & par_4 \\
\hline \multicolumn{2}{|c|}{ Aggregate distribution $\leftarrow$ Microbial entropy } & 0.507 & 0.133 & 3.822 & 0.968 & par_6 \\
\hline \multicolumn{2}{|c|}{ Aggregate distribution $\leftarrow$ Soil microbial biomass } & 0.179 & 0.529 & 0.339 & 0.735 & par_5 \\
\hline \multicolumn{2}{|c|}{ Aggregate distribution $\leftarrow$ Grassland degradation } & 0.550 & 0.411 & 1.388 & 0.181 & par_9 \\
\hline \multicolumn{2}{|c|}{ Standardized Regression Weights } & Estimate & & & & \\
\hline \multicolumn{2}{|c|}{ Soil organic matter $\leftarrow$ Grassland degradation } & 0.914 & & & & \\
\hline \multicolumn{2}{|c|}{ Microbial entropy $\leftarrow$ Grassland degradation } & -0.609 & & & & \\
\hline \multicolumn{2}{|c|}{ Soil microbial biomass $\leftarrow$ Grassland degradation } & 0.622 & & & & \\
\hline \multicolumn{2}{|c|}{ Soil microbial biomass $\leftarrow$ Microbial entropy } & 0.425 & & & & \\
\hline \multicolumn{2}{|c|}{ Aggregate distribution $\leftarrow$ Soil organic matter } & 0.399 & & & & \\
\hline
\end{tabular}


Table S3. Continued.

\begin{tabular}{|c|c|c|c|c|c|c|}
\hline & Aggregate distribution $\longleftarrow$ Microbial entropy & 0.074 & & & & \\
\hline & Aggregate distribution $\leftarrow$ Soil microbial biomass & 0.171 & & & & \\
\hline & Aggregate distribution $\leftarrow$ Microbial entropy & 0.483 & & & & \\
\hline & Aggregate distribution $\leftarrow$ Grassland degradation & 0.525 & & & & \\
\hline & & Estimate & S.E. & C.R. & $\mathrm{P}$ & Label \\
\hline & Grassland degradation & 0.917 & 0.391 & 2.345 & 0.019 & par_10 \\
\hline & eSoil organic matter & 0.151 & 0.064 & 2.345 & 0.019 & par_11 \\
\hline Variances & eMicrobial entropy & 0.577 & 0.246 & 2.345 & 0.019 & par_12 \\
\hline & eSoil microbial biomass & 0.032 & 0.014 & 2.345 & 0.019 & par_13 \\
\hline & eAggregate distribution & 0.098 & 0.042 & 2.345 & 0.019 & par_14 \\
\hline \multicolumn{7}{|c|}{ Model Fit Summary } \\
\hline \multirow{4}{*}{ CMIN } & Model & NPAR & CMIN & DF & $\mathrm{P}$ & $\begin{array}{c}\mathrm{CMIN} / \\
\mathrm{DF}\end{array}$ \\
\hline & Default model & 14 & 0.415 & 1 & 0.520 & 0.415 \\
\hline & Saturated model & 15 & 0.000 & 0 & & \\
\hline & Independence model & 5 & 86.948 & 10 & 0.000 & 8.695 \\
\hline \multirow{4}{*}{ RMR, GFI } & Model & RMR & GFI & AGFI & PGFI & \\
\hline & Default model & 0.037 & 0.985 & 0.781 & 0.066 & \\
\hline & Saturated model & 0.000 & 1.000 & & & \\
\hline & Independence model & 0.552 & 0.315 & -0.028 & 0.210 & \\
\hline \multirow{3}{*}{ RMSEA } & Model & RMSEA & LO 90 & HI 90 & PCLOSE & \\
\hline & Default model & 0.000 & 0.000 & 0.685 & 0.525 & \\
\hline & Independence model & 0.836 & 0.680 & 1.003 & 0.000 & \\
\hline
\end{tabular}

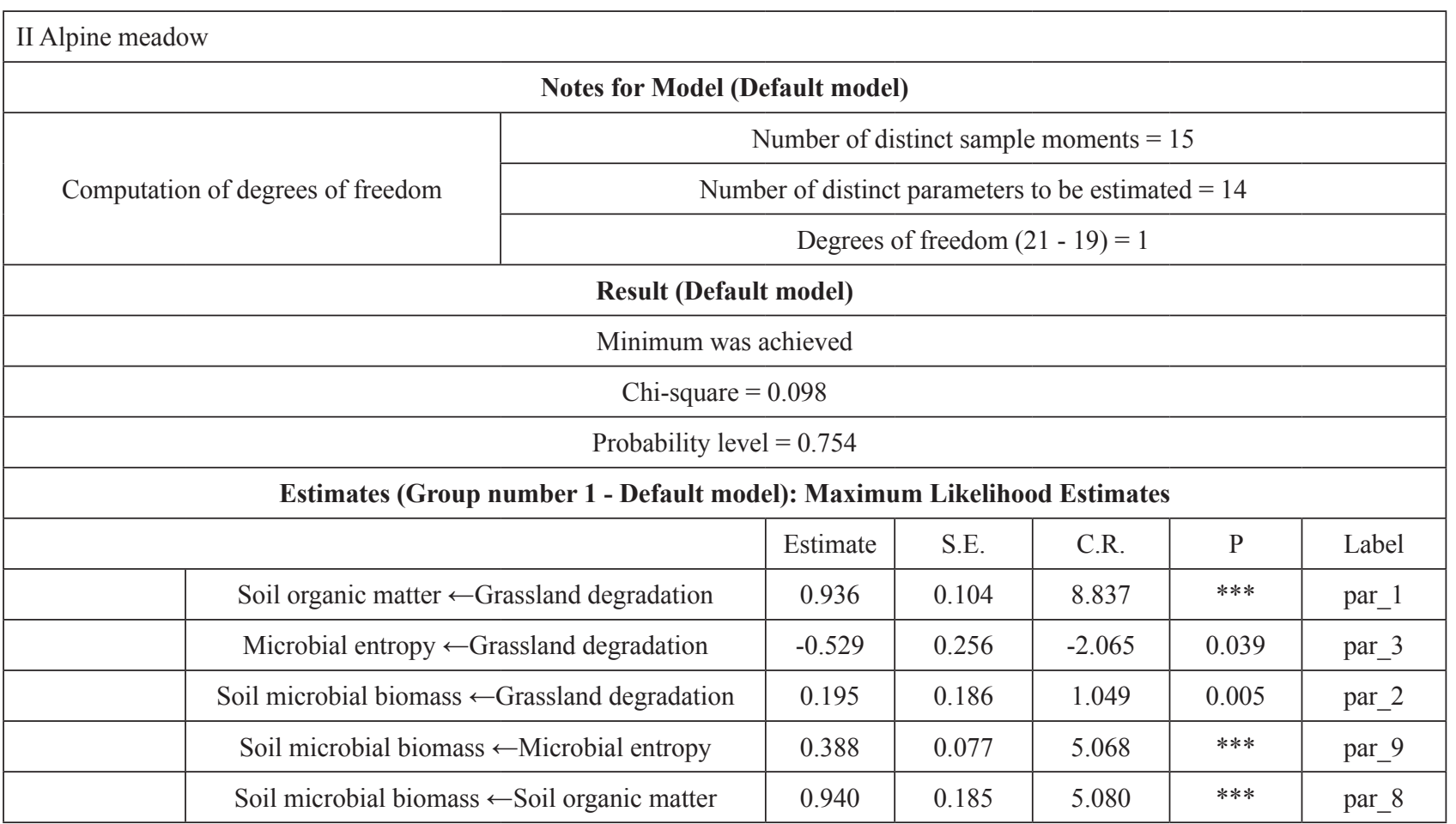


Table S3. Continued.

\begin{tabular}{|c|c|c|c|c|c|c|}
\hline & Aggregate distribution $\leftarrow$ Soil organic matter & 0.601 & 0.230 & 0.114 & 0.035 & par_4 \\
\hline & Aggregate distribution $\leftarrow$ Microbial entropy & 0.864 & 0.508 & 1.699 & 0.089 & par_6 \\
\hline & Aggregate distribution $\leftarrow$ Soil microbial biomass & 0.090 & 0.096 & 0.906 & 0.057 & par_5 \\
\hline & Aggregate distribution $\longleftarrow$ Grassland degradation & 0.213 & 0.708 & 0.300 & 0.764 & par_7 \\
\hline \multicolumn{2}{|r|}{ Standardized Regression Weights } & \multicolumn{2}{|l|}{ Estimate } & & & \\
\hline & Soil organic matter $\leftarrow$ Grassland degradation & 0.936 & & & & \\
\hline & Microbial entropy $\leftarrow$ Grassland degradation & -0.529 & & & & \\
\hline & Soil microbial biomass $\leftarrow$ Grassland degradation & 0.193 & & & & \\
\hline & Soil microbial biomass $\leftarrow$ Microbial entropy & 0.384 & & & & \\
\hline & Soil microbial biomass $\leftarrow$ Soil organic matter & 0.931 & & & & \\
\hline & Aggregate distribution $\leftarrow$ Soil organic matter & 0.598 & & & & \\
\hline & Aggregate distribution $\leftarrow$ Microbial entropy & 0.863 & & & & \\
\hline & Aggregate distribution $\leftarrow$ Soil microbial biomass & 0.109 & & & & \\
\hline & Aggregate distribution $\longleftarrow$ Grassland degradation & 0.213 & & & & \\
\hline & & Estimate & S.E. & C.R. & $\mathrm{P}$ & Label \\
\hline & Grassland degradation & 0.917 & 0.391 & 2.345 & 0.019 & par_10 \\
\hline & eSoil organic matter & 0.113 & 0.048 & 2.345 & 0.019 & par_11 \\
\hline Variances & eMicrobial entropy & 0.042 & 0.018 & 2.345 & 0.019 & par_13 \\
\hline & eSoil microbial biomass & 0.661 & 0.282 & 2.345 & 0.019 & par_12 \\
\hline & eAggregate distribution & 0.558 & 0.238 & 2.345 & 0.019 & par_14 \\
\hline \multicolumn{7}{|c|}{ Model Fit Summary } \\
\hline \multirow{4}{*}{ CMIN } & Model & NPAR & CMIN & $\mathrm{DF}$ & $\mathrm{P}$ & CMIN/DF \\
\hline & Default model & 14 & 0.098 & 1 & 0.754 & 0.098 \\
\hline & Saturated model & 15 & 0.000 & 0 & & \\
\hline & Independence model & 6 & 66.008 & 10 & 0.000 & 6.601 \\
\hline \multirow{4}{*}{ RMR, GFI } & Model & RMR & GFI & AGFI & PGFI & \\
\hline & Default model & 0.012 & 0.996 & 0.947 & 0.066 & \\
\hline & Saturated model & 0.000 & 1.000 & & & \\
\hline & Independence model & 0.444 & 0.415 & 0.123 & 0.277 & \\
\hline \multirow{3}{*}{ RMSEA } & Model & RMSEA & LO 90 & HI 90 & PCLOSE & \\
\hline & Default model & 0.000 & 0.000 & 0.547 & 0.758 & \\
\hline & Independence model & 0.714 & 0.556 & 0.882 & 0.000 & \\
\hline
\end{tabular}



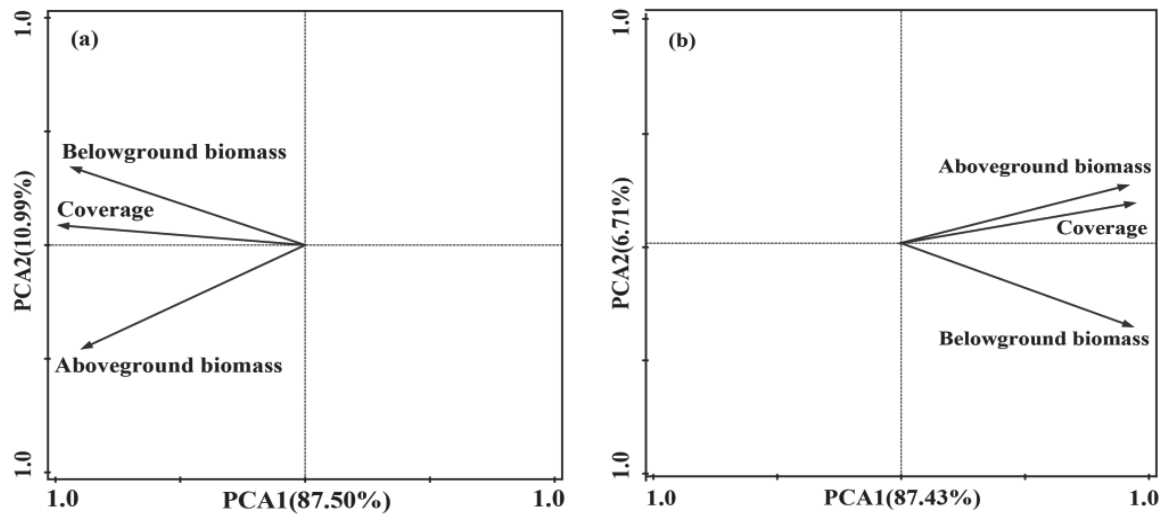

Fig. S1. Species-sample bi-plot of Principal Component Analysis (PCA) of grassland degradation in alpine steppe a) and alpine meadow b). Percentages along the axes correspond to the amount of explained variability in grassland degradation.
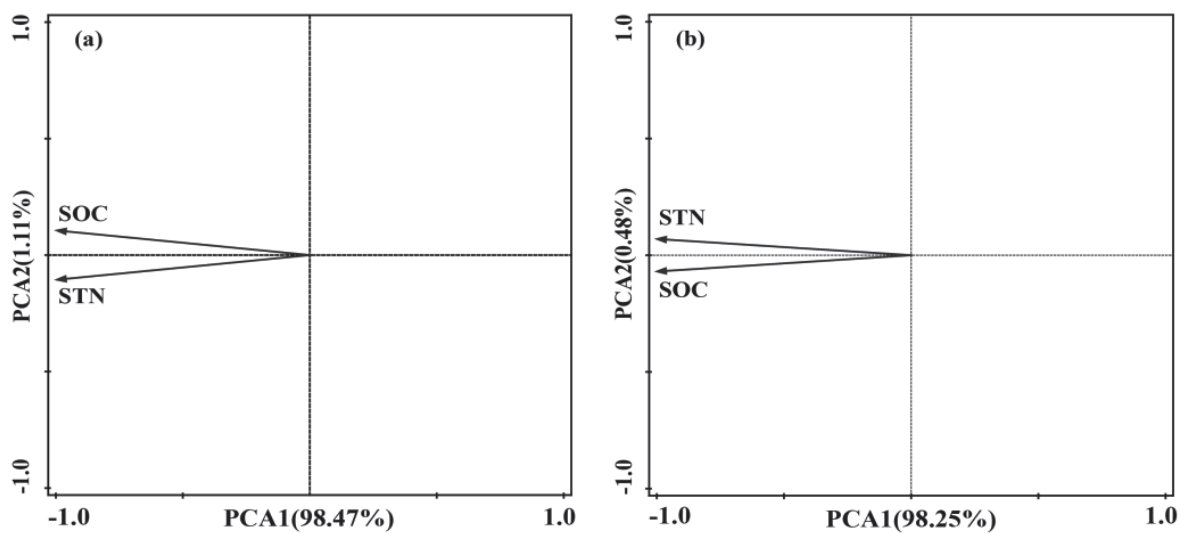

Fig. S2. Species-sample bi-plot of Principal Component Analysis (PCA) of soil organic matter in alpine steppe a) and alpine meadow b). Percentages along the axes correspond to the amount of explained variability in soil organic matter. SOC - Soil organic carbon; STN - Soil total nitrogen.
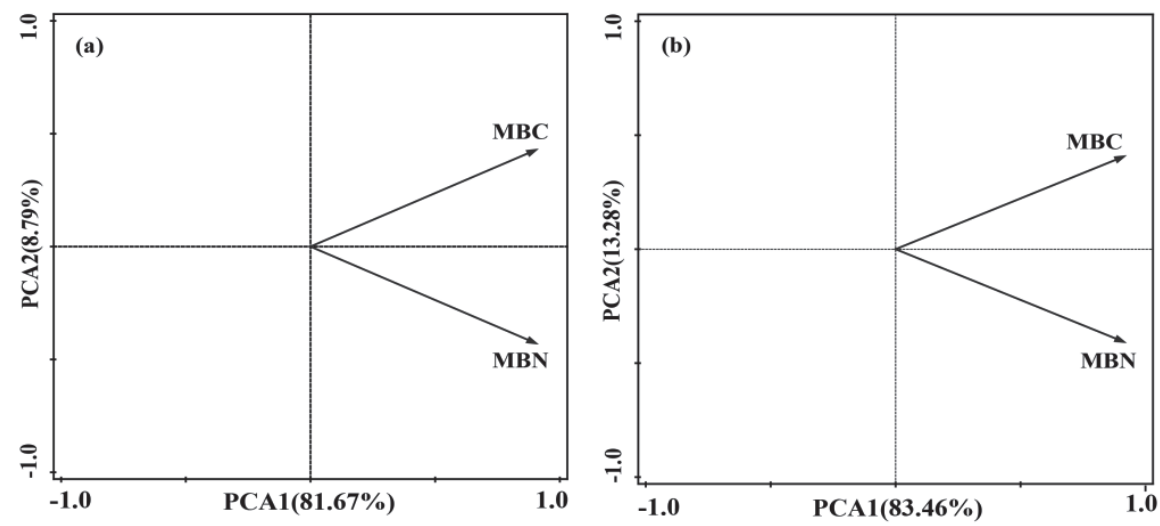

Fig. S3. Species-sample bi-plot of Principal Component Analysis (PCA) of soil microbial biomass in alpine steppe a) and alpine meadow b). Percentages along the axes correspond to the amount of explained variability in soil microbial biomass. MBC - Microbial biomass carbon; MBN - microbial biomass nitrogen. 

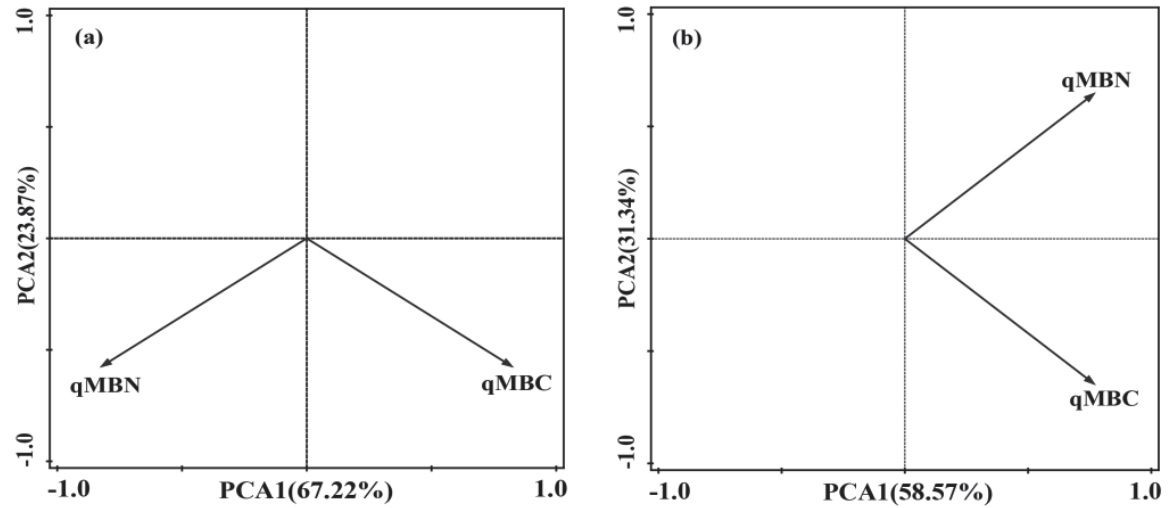

Fig. S4. Species-sample bi-plot of Principal Component Analysis (PCA) of microbial entropy in alpine steppe a) and alpine meadow b). Percentages along the axes correspond to the amount of explained variability in microbial entropy. qMBC - Microbial entropy carbon; qMBN - Microbial entropy nitrogen.
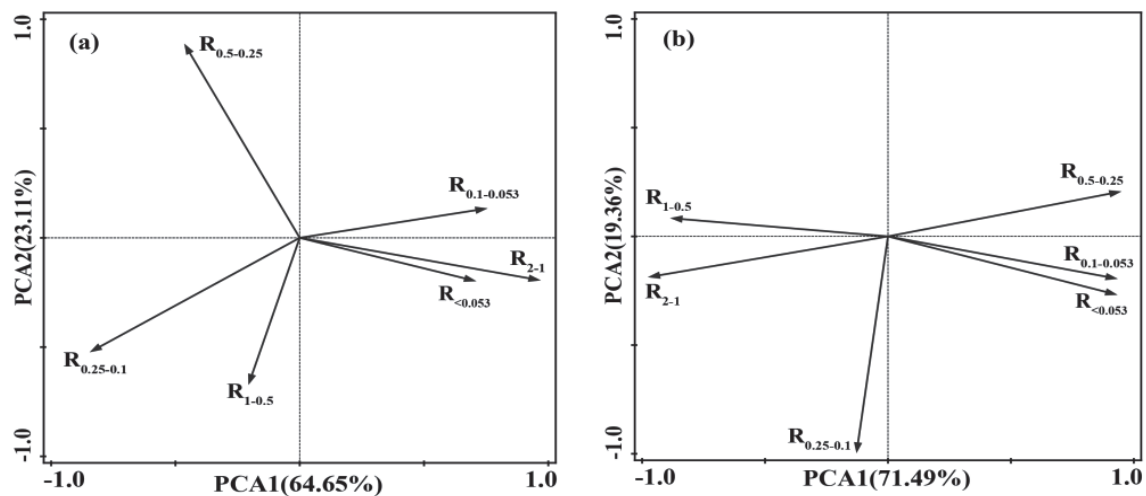

Fig. S5. Species-sample bi-plot of Principal Component Analysis (PCA) of aggregate distribution in alpine steppe a) and alpine meadow b). Percentages along the axes correspond to the amount of explained variability in aggregate distribution. 